\title{
Jaś Elsner
}

\section{Ornament, figure and mise en abyme on Roman sarcophagi*}

For Janet Huskinson

Figure and ornament are two elements of Roman art endlessly repeated across the many media and genres of Roman image-making. ${ }^{1}$ This process of replication and the multifarious ways it is used for decorative embellishment, means that it is rather artificial to separate the two. ${ }^{2}$ When there are paintings or reliefs that adorn the surfaces of monuments (exteriors, interiors, fronts, sides and backs - with the decision not to adorn any one face in itself decoratively significant), both figure and ornament are intrinsic parts of an empire-wide visual system that makes all kinds of replicative claims to collective culture, identity, sovereignty and power. ${ }^{3}$

The role of replication in Roman art is one of the oldest, and currently still one of the hottest, topics in the subject. From the great fields of Meisterforschung and Kopienkritik of the late nineteenth and early twentieth century (which over-emphasised Roman secondariness in relation to the priority of lost Greek models), to the new early twenty-first-century orthodoxy of 'emulation' (which preserves the Roman-

\footnotetext{
* I am particularly grateful to the volume's editors - Michael Squire and Nikolaus Dietrich - as well as to Mont Allen, Bjoern Ewald, Janet Huskinson and Katharina Meinecke for their many helpful suggestions.

1 By 'ornament' I mean here non-figural decorative framing - at any rate, in much of Roman art. For discussion of the historiography, cf. Squire's introduction to this volume - with Neer's chapter in particular. On the distinctive language of Roman ornamenta, see Barham's chapter in this volume, along with the contributions by Platt, Reinhardt and Trimble.

2 I have deliberately put this in a low-key and understated way, since this is a short chapter about a few sarcophagi. But let me be clear: it constitutes a fundamental rejection of the assumptions formulated by Immanuel Kant about parerga, 'ornaments' that function 'externally as a complement' to the main thing 'for example, the frames of pictures or the draperies of statues or the colonnades around palaces' (see Kant 1987, 72, with particularly rich discussion and bibliography in Platt and Squire 2017, esp. 38-59; cf. Squire's introduction to this volume, 18-20, along with Neer, 206-209, Platt, 241-242, 252-253 and Barham, esp. 280-283). Beyond even Derrida's deconstruction of the Kantian parergon (Derrida 1987, 15-147), I want to assert that there is only representation at play - neither figure nor ornament, neither centre nor periphery, but just an endlessly replicative, but formally and typologically relatively limited parade of visual signs that Roman art at any rate constantly rearranged and reformulated in something closer to a 'life of forms' (see Focillon 1942, a topic on which I am grateful to Nadia Ali for discussion).

3 For recent and interesting reflections on ornament, see - in addition to Squire's introduction to this volume - the special volume of Perspective (2010) on 'ornement/ornemental'; Hölscher 2009 (now supplemented by Hölscher's chapter in this volume); Beyer and Spies 2011. A classic account remains Camille 1992, 9-56.
} 
Greek relationship but gives agency and value to Roman appropriations), there has been (perhaps too much) emphasis on models and copies or variants, rather than the free play of repeated motifs (including both figures and all kinds of decorative forms) that ultimately replicate each other in a riot of ornament. ${ }^{4}$ In particular, the great corpora of Roman art - where there is some possibility of quantitative statistical analysis as well as qualitative discussion (I am thinking of sarcophagi in particular and also Roman wall-painting) - offer rich decorative replications from the smallest of repeated motifs to whole replicated iconographies, which may be argued to have had significant impact on viewers by their very referencing and reiterating of normative visual themes. One area where this had some impact was in the realm of visual memory. ${ }^{5}$ But another lies in mortuary art where repetition of commemorative monumental types (ash urns, sarcophagi, funerary altars, funerary reliefs and so on) alongside the repetition of the kinds of ornament most frequently found on such objects (from portraits via wreaths to architectural elements) ultimately may be thought to comment on the repetition of death itself as an endless and unavoidable replication, even if the carcass, bones or ashes now in a memorial casket were once the basis of an individual. ${ }^{6}$

In this chapter I want to look at this aspect of replication by exploring what I shall call mise en abyme (returning to an aspect already discussed by Jennifer Trimble, in the context of the Tomb of the Haterii: $346-348) .{ }^{7}$ This, in my use of the term here, is when one element or motif within a decorative surface (strigillation, say, or the use of garlands) replicates, or alludes, to and hence potentially comments on, other elements in the same object or the class of objects in which it occurs. But the trope is profound in Roman art, especially in the relation of framed panels and framing schemes in wall-painting, and it extends to figures no less than to ornament, for example, in

4 Meisterforschung and Kopienkritik: Furtwängler 1893; Lippold 1923; Ridgway 1984 with Hallett 1995; and discussions of the issues in Junker, Stähli and Kunze 2008 and Squire 2011, esp. 372-375. Emulation: Gazda 2002; Perry 2005; Kousser 2008. Seriality: Marvin 1993; Anguissola 2005; Settis 2015. Replication: Trimble 2011; Anguissola 2012. For discussion of all these themes, see also Reinhardt's chapter in this volume - as well as the chapters by Barham (on Roman cultural ideas of the 'ornamental') and Platt (discussing Roman wall-painting).

5 See e. g. Elsner and Squire 2016.

6 See Platt 2012, esp. 213-218 on tombs as frames (further expanded and elaborated in her chapter in Platt and Squire (eds.) 2017); cf. also Trimble's chapter in this volume.

7 The term comes from literary criticism: see the discussion of Dällenbach 1989. However, in the passage from Andre Gide (of 1893) with which Dällenbach opens, where he claims the concept was used for the first time, Gide begins by referring to the use of mirrors in paintings by Memling, Metzys and Velasquez, before moving on to literary examples such as the play within a play in Hamlet: cf. Dällenbach 1989, 10-12, citing Gide 1943, 44-45. The trope extends all the way back to the beginnings of Greek literature: cf. Squire 2013 on the Homeric 'shield of Achilles' ecphrasis (esp. 165-179 on the ensuing visual replications of the literary mise en abyme in Graeco-Roman art). 
such popular themes as Narcissus gazing at himself. ${ }^{8}$ This specific quality of self-referentiality (not by any means an uncommon feature of the visual life of Roman sarcophagi) is itself a subset of a bigger thematic whereby such repeated elements effectively bring to mind (and reflect on) the more general use of such themes and motifs not just on the specific object itself but within the whole corpus of similar objects. Stylistic aspects of this kind of replication and valuation in Roman art have in the past been interpreted as a means of communication, even as a visual language, ${ }^{9}$ but arguably it is much less systematic than a semantic or linguistic system and rather more restricted in the range of motifs employed. Rather than a linguistic system of semantic communication, I would argue that a much better analogy for the workings of Roman art is the discursive workings of Roman rhetoric - also a system of limited tropes, motifs and figures deployed within highly conventional forms to make an extraordinary range of diverse and sometimes highly original works of literary art. ${ }^{10}$

Now, in my model, mise en abyme is a formal replicative device that has the quality of reflexivity in relation to the object it decorates. ${ }^{11}$ The significance of such reflexivity in relation to the object(s) on which it reflects is not only formal. It is generative of meaning at the point of viewing. The range of meanings in ancient Roman art and culture are not easily determined since some are culturally coded in ways to which we may no longer have access, and some may always have been subjective. Nor is it my intention to try to determine the culture's deeper reflexes for the generation of meaning. Nonetheless, in the context of objects made to commemorate a death and whose form contains the deceased, there are at least some constraints within which meaning is likely to have been controlled. However, it is my aim here - using the example of sarcophagi - to suggest that replicative formalism in the production of Roman art was in fact capable of generating the means for the creation of meaning in Roman culture.

The great number - indeed ubiquity - of Roman sarcophagi and their very familiarity to students of Roman art, which can lead to a kind of taking for granted and even contempt, belie the poignancy of each individual item. For each was set up, at some considerable expense and effort, ${ }^{12}$ as a memorial to a life and as the marker of an absence. These objects - whether carved specially or bought off the shelf, whether adorned with images of the deceased (individualised finished portraits or ones with

\footnotetext{
8 See Elsner 2007, 132-176 for discussion.

9 Notably Hölscher 2004.

10 See especially Elsner 2014a. For two new and vibrant discussions of mise en abyme in Roman relief sculpture, see the chapters by Reinhardt and Trimble in this volume.

11 See Dällenbach 1989, 41-54 on reflexivity (although talking of texts).

12 See now Russell 2013, 256-310. For a useful overview of the economics of Roman art (but with no discussion of sarcophagi), see Harris 2015. On questions of the market, see Galinier 2013; on issues of production, see Huskinson 2015, 35-62.
} 
blank and unfinished faces $)^{13}$ or with no representation of the dead person - were a permanent reminder of loss and a claim for memory that would last as long as the stone of the coffin itself would last. ${ }^{14}$ Yet, in their denotation of a specific bereavement within a family, sarcophagi are remarkably replicative and hence generalising in their iconographies and visual narratives - as if buying the deceased into a world of conventional socialisation whether in the mythologies or the cultural tropes of the Roman empire, a world that has been memorably defined as one of 'culture and classicism'. ${ }^{15}$

The Roman sarcophagus - as a unique form of consolatory commemoration which includes the dead body inside its structure, ${ }^{16}$ and which mimics that body in shape ${ }^{17}$ - always has the potential for a kind of mise en abyme: its monumental and visual rhetorics - so permanent because in stone - merge into the emptiness of the absence they both contain and deny. In this chapter I want to explore this issue of the intrinsic emotional resonance of the sarcophagus, like a bandaged wound that remains tender, by extending the memorial logic of the coffin containing a corpse to examine certain features of mise en abyme in the decorative language of the ways in which Roman sarcophagi are articulated. I want to look at ways in which the ornamental discourse of coffin decoration calls into question its relations with its own materiality, the visual systems within which that operates and the body it contains.

In the context of sarcophagi, figural decoration in human form always carries a potential reference to the no-longer-fully-human remains of the being that was once alive and that is now within the casket. And all forms of ornamentation (figural and 'decorative') themselves cover the blank space of the casket's exterior, calling attention to a horror vacui which is itself potentially metaphorical of the horror vacui of absence and loss that is defined by the presence of the remains within the box. The sarcophagus, as consolatory monument, is already a kind of ornament of the dead person within it, as well as a figural mimêsis of his or her shape in its very form. Its relief decoration (sometimes gilded, often painted we may presume) was a further series of ornaments for the monumental memorial, which in different ways steered viewers' grief, consoled them for their loss and delivered an encomium for the figure within. The recession of decorative mise en abyme I shall discuss is itself structured by the very hierarchy of relief ornament, funerary monument and dead body, in which each element potentially comments on the others. It may be that within the funerary

13 On blank heads, see Engemann 1973, 76-78; Andreae 1984; Huskinson 1998; Birk 2013, 55-58; Russell 2013, 301-307; Elsner forthcoming a.

14 On funerary display and context, see Borg 2013, 213-240; Meinecke 2014; Huskinson 2015, 63-73. On funerary cult, see Meinecke 2013.

15 See Nock 1946, esp. 166.

16 For consolation see e. g. Lorenz 2011 and Newby 2014.

17 See Elsner 2012, 179-180. 
structure of body, coffin, monument and decoration we should not accord primacy to any one element (such as the deceased person's corpse).

In what follows, I will open by looking at mise en abyme in a single case study of a garland sarcophagus, and from there move to various broader reflections focusing on strigillation. First, I will consider the relation of strigillated columns alongside strigillated panels in a large group of Roman sarcophagi. Then I will move to strigillated caskets with figural mise en abyme (in the case of the image of Narcissus looking at his own reflection), before turning to examine the specific isolation of deity figures (Dionysus and Jesus) in aedicules with strigillated columns at the centre of five panel sarcophagi with bands of strigillated ornament. Finally, I shall return to the theme of images of strigillated items (vases and sarcophagi themselves) within the decorative narrative of sarcophagus reliefs, that appear to comment self-reflexively on the whole genre of this class of monument, its decoration and the specific casket on which they have been carved. My conclusion will attempt to broaden these very close-focused analyses into a larger reflection on the nature of Roman image-making.

\section{Mise en abyme in a single sacrophagus}

As a starting-point, consider a sarcophagus of $c$. AD 160, which survives in relatively poor condition, without a lid (whose decoration would obviously have made a difference to the resonances of the whole), in the Palazzo Pallavicini-Rospigliosi in Rome (Fig. 13.1). ${ }^{18}$ On either side of the front, two male nude putti face each other holding a garland with a winged Medusa head as a kind of mask in the space above the garland. In the centre - flanked by these motifs - is an image of a robed woman, ${ }^{19}$ without an individualised portrait, one presumes intended to be the deceased, who reclines on a couch with a bird, conceivably an eagle, by her head (Fig. 13.2). The base of the couch is made of two winged griffins facing outwards at each leg and a naked Eros in the centre in a dancing posture holding two garlands, one in each hand, that extend from the wings of the griffins at the couch's legs. These garlands have circular paterae above them. The reclining figure emulates - in a commemorative form that evokes her in life - her own dead body also reclining inside the casket but no longer sitting up frontally or addressing a viewer with her gaze. It may be that she lies on her deathbed and the eagle is about to take off to signal apotheosis, or she may lie in an idealised image of her former life, with the bird as a pet: this is unclear, and both intimations may be in play. At any rate, there is a great deal of winged imagery

18 Found in Ostia: see Herdejürgen 1996, no. 127; Amedick 1991, no. 212; also - briefly - Birk 2013, 131, and no. 537.

19 At least I think from the photograph that it is a woman - and I follow Herdejürgen 1996. 


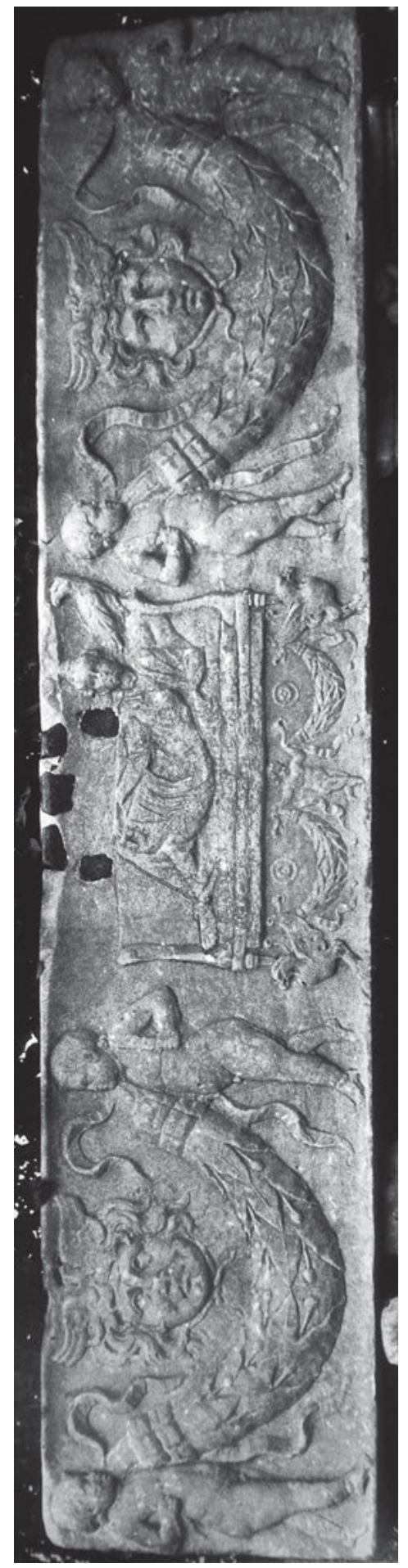

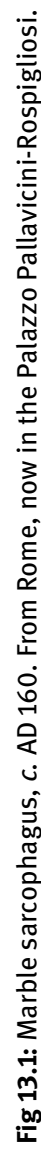




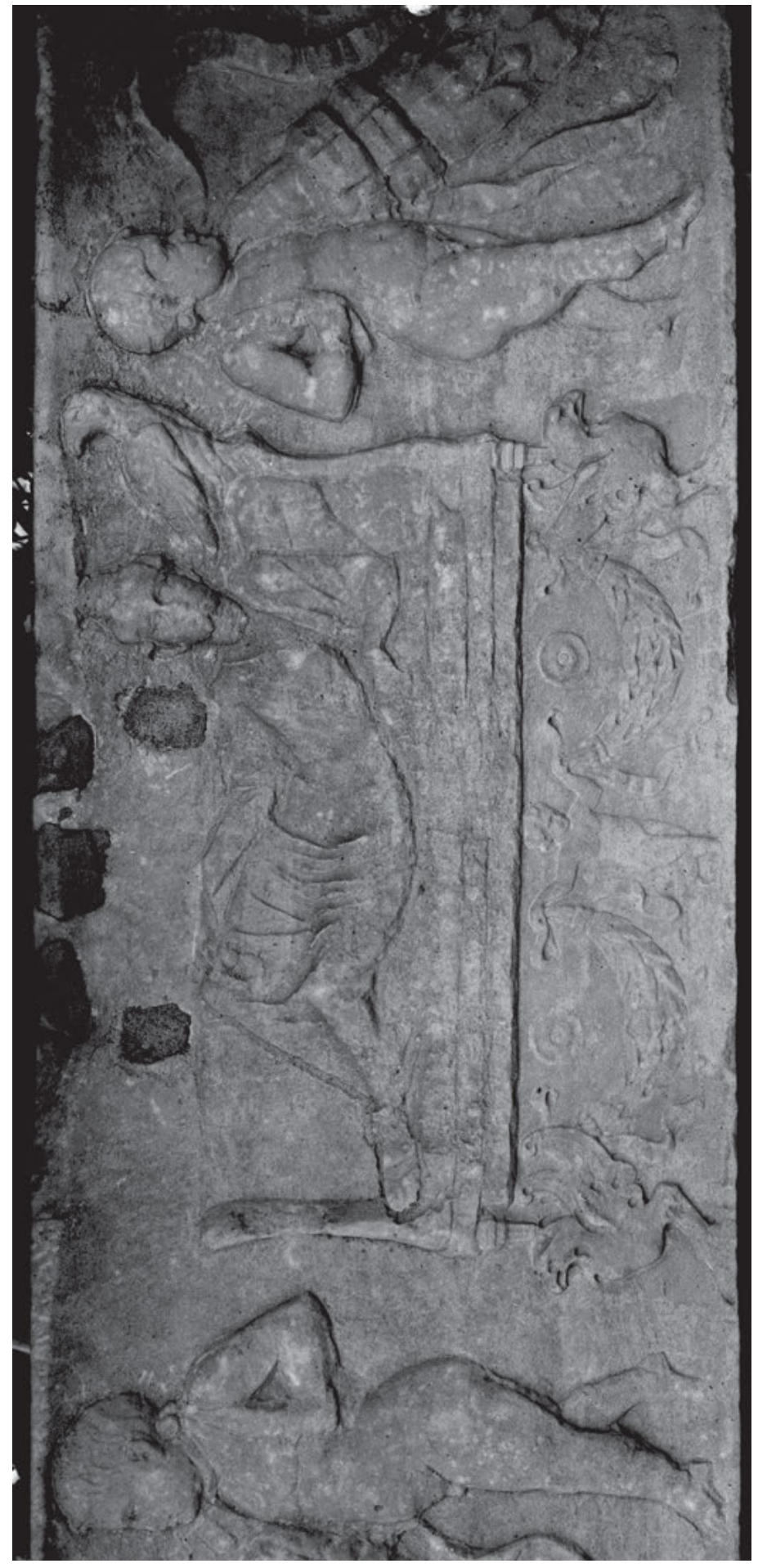

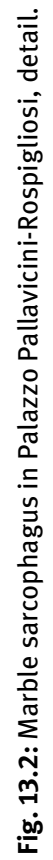

Bereitgestellt von | De Gruyter / TCS 
here, much of it mythological (Medusa and the griffins) as well as the eagle, implying perhaps a desire to take off, an aspiration to abandon earthly interment. We may add that there is a plethora of ribbons swirling about the putti, the garlands and beneath the Gorgons' heads. The base of her couch replicates the iconography of the coffin as a whole - wings, garlands, putti, motifs that fill the spaces above the garlands. Her couch becomes a variant replication of the whole sarcophagus, its intimations of death and potential apotheosis effectively playing to the bigger theme of the coffin but also putting it into question through a kind of miniature reiteration by the technique of mise en abyme. The whole set of decorative choices effectively sets up a self-referential game that interrogates gently and poignantly (in the context of mourning and consolation) the theme of dying, death and apotheosis.

The gorgoneia - threatening petrification to their viewers - themselves play on whether the stone image of the deceased on the base is more or less dead, more or less petrified, than the corpse itself. ${ }^{20}$ There is always a potential joke in the Gorgon's head (which turned its viewers into stone) ${ }^{21}$ being made from stone, and arguably represented as itself petrified, since usually becoming stone is what results from confrontation with a Gorgon. In this case, since the Gorgon's head is duplicated, one example might be seen as an image of the original and the other as a representation of its replica, frozen in stone by confrontation with the original - but we cannot decide which of the two has the priority; indeed, for a Gorgon's head to be petrified by Medusa, two original Gorgons, each petrifying the other, is surely implied. Since this issue touches on the making of art (no art is as lifelike as the statuary forged from life into stone by the sight of Medusa), the mise en abyme of replicative gorgoneia is also an interrogation of the nature of artistry in this object and in the embellishment of all sarcophagi, a theme of repeated insistence in figural decoration on sarcophagi since so much of it puts its figures on pedestals as if they were statues. This kind of play effectively offers in figural form reflections on the replication of other motifs such as garlands and putti. We may ask, moreover, what is at stake in the place of the Gorgons' heads being taken by paterae in the imagery below the couch? Are the stone-frozen intimations of Medusa what replaces the ritual action of libation and sacrifice when one moves from the living (in the figure reclining on a couch) to the dead (in the body reclining inside the casket)? The garlands and paterae of the couch imply offerings - perhaps from the reclining woman to the deceased, from her living self to her dead self - or perhaps (like the garlands on the two sides) from the surviving relatives to the dead. Is the couch a bier? Does its figuration at the centre of the sarcophagus' main front work as prefiguration or memorialisation of the coffin on which it is depicted and whose iconography it both borrows and subverts?

20 For some implications of Gorgon imagery, see e. g. Mack 2002 and Grethlein 2016.

21 On Ovid's account of this (Met 4.663-5.235), see Hardie 2002, 178-186. 
Among our surviving sarcophagi, this is a unique object in terms of the intimacy with which its decoration plays self-reflexively on its own themes using these particular iconographic features. Its unusual nature has caused some suspicion that it may have been reworked in the eighteenth century, which would mean that certain aspects of what I have been discussing are the result of modern decorative interventions. ${ }^{22}$ Yet all the features themselves are ubiquitous. We have frequent examples of sarcophagi with putti holding garlands, ${ }^{23}$ and of gorgoneia over garlands, ${ }^{24}$ while there are also (fewer) cases of paterae over garlands, ${ }^{25}$ and of griffins and cupids holding garlands or griffins in association with this range of imagery. ${ }^{26}$ We may add that there are plenty of variations on this iconography in the sarcophagi made in the east of the empire. ${ }^{27}$ So the Pallavicini-Rospigliosi sarcophagus, in casting a miniaturised self-reflection on the imagery within its own surface, simultaneously offers a more general perspective (a kind of object-specific mise en abyme) on this whole class of interconnected imagery. To anyone familiar with the range of types, the thematic would have been instantly recognisable.

Thus the Pallavicini-Rospigliosi sarcophagus not only comments on its own imagery, but through doing so both comments on and participates in the general run of the kinds of imagery it uses. This is one of the effects of the replicative model of constructing works of art through given formulae and typological iconographies made up of repeated elements - building a new and unique monument out of a range of known and common ornamental themes. This thematic ubiquity (and by post-Renaissance aesthetic standards the lack of decorative originality) is not only one of the key fea-

22 See Herdejürgen 1996, 149; Amedick 1991, 156, and esp. Wrede 1981, 96-99. The case depends on comparison of the Pallavicini-Rospigliosi sarcophagus with a print by Piranesi of the sarcophagus he saw in the Palazzo Governo, published in 1778 (illustrated by Wrede 1981, 98, fig. 15). Piranesi shows no griffins, swags, putti or paterae beneath the klinê, but rather an empty tabula ansata. There is a variety of options here: one is that the sarcophagus was definitely recut after the 1780s; another is that Piranesi in fact shows a different but similar sarcophagus, now lost; another is that he free associated, since his print must be based on a prior sketch which may not have been fully clear and was anyway not founded on modern or photographic standards of accuracy. Note that other differences between the print and the Pallavicini-Rospigliosi sarcophagus include the heavy rim around all the figural iconography on both the top and bottom, which was certainly never the case in the existing object.

23 For instance: Herdejürgen 1996, nos. 15, 16, 17, 18, 23, 30, 31, 36, 38, 39, 41, 42, 43, 44, 45, 46, 47, 48, 49, 50, 51, 52, 53, 54, 56, 58, 59, 60, 61, 63, 64, 65, 70, 71, 73, 76, 77, 80, 84, 88, 91, 93, 94, 97, 98, 99, $100,101,102,104,106,107,109,110,111,112,113,114,116,117,118,122,123,125,126,127,128,129,131$, $132,133,134,137,139,140,141,142,143,145,146,147,149,152,155,156,157,158,160,161,166,172,176$, 179, 180, 182, 183, 185.

24 For example: Herdejürgen 1996, nos. 6, 15, 20, 50, 72, 78, 82, 86, 88, 93, 94, 106, 112, 113, 122, 123 , 139, 142, 143, 146, 147, 162, 169, 179, 180, 181, 183.

25 Herdejürgen 1996, nos. 15, 37, 162.

26 Herdejürgen 1996, nos. 16 (griffins and cupids with garlands); 84, 90, 118, 128, 131 (griffins in connection with the imagery of garlands and cupids).

27 See e. g. Ișik 2007a, nos. 16, 27, 28, 32, 34, 35, 38, 44; also Ișik 2007b. 
tures of Roman art, but one of the qualities that resonates with (indeed replicates) the ubiquity and universality of death which these monuments address directly, while at the same time offering a specific and perhaps even unique take on this problem, as in this casket. ${ }^{28}$

\section{Strigillation: Columns and panels}

One of the most popular kinds of sarcophagus is the strigillated type - so common that there has never been an attempt at a corpus. ${ }^{29}$ Strigillation is that distinctive surface treatment - so common in sarcophagi, including very expensive ones - where a repeated series of curvy fluted lines is cut into the marble to make a ripple effect in relief. ${ }^{30}$ There is in fact a kind of mise en abyme about the strigillated line itself, which curves back on itself in an 'S'-shape and in many examples is made to echo in reverse the ' $\mathrm{S}$ '-curves on the other side of the same sarcophagus. Another very common feature of sarcophagi, again so common that no corpus has been attempt$\mathrm{ed},{ }^{31}$ is the use of columns to construct arcades or aedicules across the main decorative face, within which figural scenes or images of statues may be placed; many of these columns are themselves strigillated. By strigillated columns, I mean ones with spiral (as opposed to vertical) fluting, whose visual effects are similarly dynamic, both in surface decoration and relief texturing, to panels of strigillation. ${ }^{32}$

My interest here is the model of using aedicules with strigillated columns in the context of a partly or largely strigillated sarcophagus. ${ }^{33}$ For instance, in the Campo Santo at Pisa, there are two examples of this phenomenon. The piece, which has been variously dated to the $160 \mathrm{~s}$ and the $260 \mathrm{~s} \mathrm{AD}$ (with a fourteenth-century inscription saying NOCCI CASTILIONIS SEPULCRUM), is a typical 'five-panel' sarcophagus with an aedicule in the centre within which stands a frontal man in a toga with a scrinium for book rolls on the ground to his right (Fig. 13.3). He is flanked by panels of strigillation. To the far left is a man in a tunic facing inwards to a flaming altar, while to

28 For individuality amidst the schematism in relation to strigillated sarcophagi, see Huskinson 2012, esp. 82.

29 For brief accounts, see Koch and Sichtermann 1982, 73-76; Ewald 1999a, 335-337; Koch 2000, 4553; Huskinson 2012, and now esp. Huskinson 2015 for a commanding and scintillating discussion notably 75-102 on issues of decoration and 103-111 on questions of viewing.

30 See Huskinson 2015, 8-11.

31 See Koch and Sichtermann 1982, 76-80, and Koch 2000, 42-45, for brief discussions.

32 'In effect, the panels of curved fluting recall spiral reputed columns rolled out across the flat walls of the sarcophagus' (Huskinson 2015, 8-9); cf. Chiarlo 1974, 1341, and Turcan 1999, 164.

33 On the strigil motif and its use in all kinds of Roman decoration, see Gütschow 1931, 113-118, and Huskinson 2015, 20-22, 47-49, 76-80, 92-94; on columns and pilasters, see Huskinson 2015, 24; on aedicules, see Huskinson 2015, 82. 


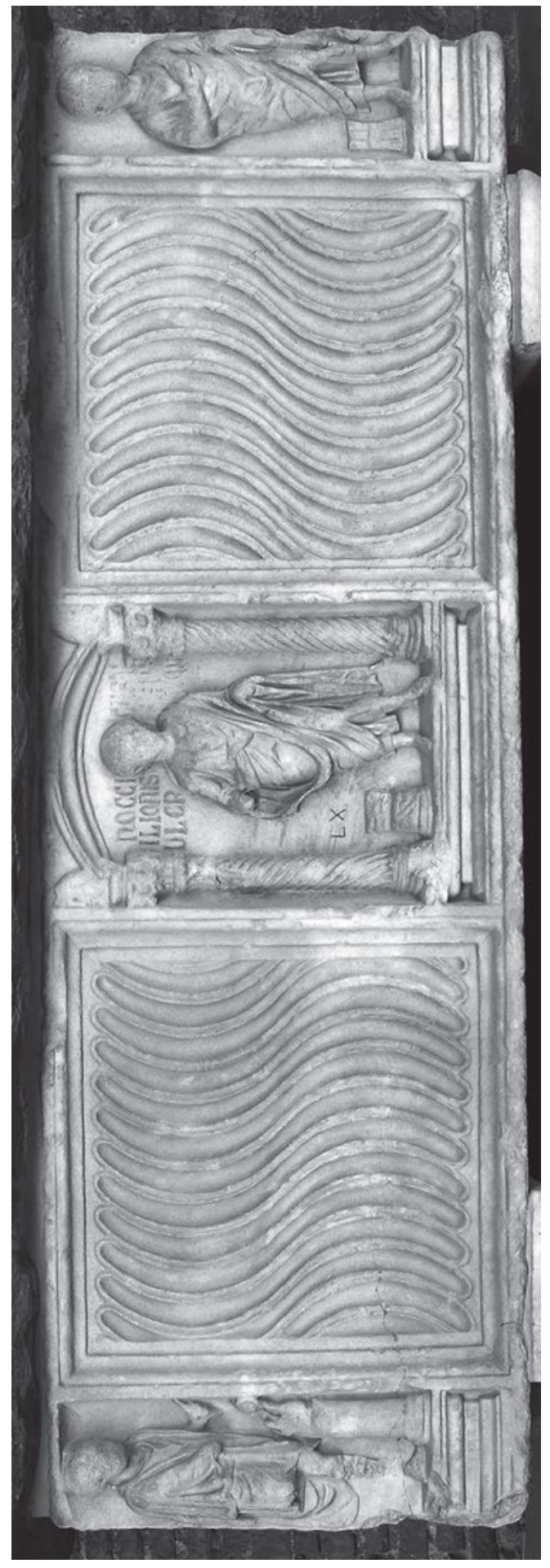

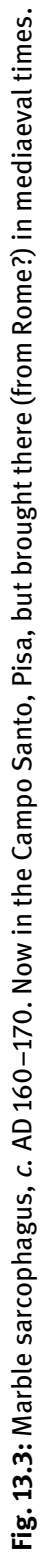

Bereitgestellt von | De Gruyter / TCS 
the right is another frontal man in tunic and pallium also with a bundle of rolls to his right. None of the heads appears to have been finished, although it may be that they are just badly worn. ${ }^{34}$ All three figured scenes are on bases, with the implication that they might be statues or are at least distanced from the viewer as potential works of art. The panels of strigillation by contrast expand across their whole allotted space on the casket front, but are encased in frames. ${ }^{35}$ Here we are offered a male-centred iconography of ritual practice and paideia - the deceased (perhaps depicted three times) defined by his accomplishments in the normative models of self-cultivation among the Roman elite.

A second instance, from a sarcophagus of the Severan period (c. AD 230), has an aedicule containing two young men with fine portrait heads in the centre, both wearing togas, flanked by scrinia and with the youth on the left holding a roll (Fig. 13.4). ${ }^{36}$ This scene has panels of strigillation to either side, with female and male figures at the left and right ends, both frontal with unfinished heads, and the latter in military dress. All the figures stand on bases, but this time the panels of strigillation have no frame to left and right, being cut off abruptly by the figured scenes, although they are elaborately framed at top and bottom. ${ }^{37}$ In this instance, the figures consistently refuse constraint by their frames - the boys' heads edge against the roof of the aedicule, the arm and cloak of the one on the left overlapping the strigillated column that is meant to contain him. The robes of the woman to the far left transgress the abrupt ending of the strigillation and appear to flow into and merge with it, while the man on the far right gestures over and into the strigillated patterning that encroaches upon him to his right hand side, while his left shoulder and cloak overlap and emerge out of the squared niche in which he is placed. This casket is a lenos in form that has lions' heads with rings through them (like faux handles or door knockers) at the back (Fig. 13.5). ${ }^{38}$ It may be that this group is a family though it is not clear now if the young sons were commemorated before (and therefore by) their parents, whose heads were intended for portraits that they never received, or whether it was the sons as donors who had their heads carved, leaving their deceased parents in a state of perpetual blankness. These last questions make this a particularly interesting and problematic sarcophagus in thinking about its life history or object biography. ${ }^{39}$

34 Mont Allen tells me that he and Sarah Madole recently re-examined this piece in Pisa (in 2016) and concluded firmly that the heads were unfinished rather than just worn.

35 See Arias et al. 1977, no. C8 est.; Ewald 1999b, no. F 5 (57 and 188); Reinsberg 2006, no. 55; Huskinson 2015, 135-136. All agree on a later third-century dating, except for Reinsberg who suggests AD 160-170. Generally, on borders and frames for panels of strigillation, see Huskinson 2015, 94-97.

36 Generally, for portraiture on strigillated sarcophagi, see Huskinson 2015, 117-145.

37 See Arias et al. 1977, no. B1 est.; Reinsberg 2006, no. 54; Andreae 1984, 110-111; Borg 2013, 198 and 204; Huskinson 2015, 54-55.

38 See Stroszeck 1998, no. 50.

39 See Huskinson 2011, 61-64 and 73. 


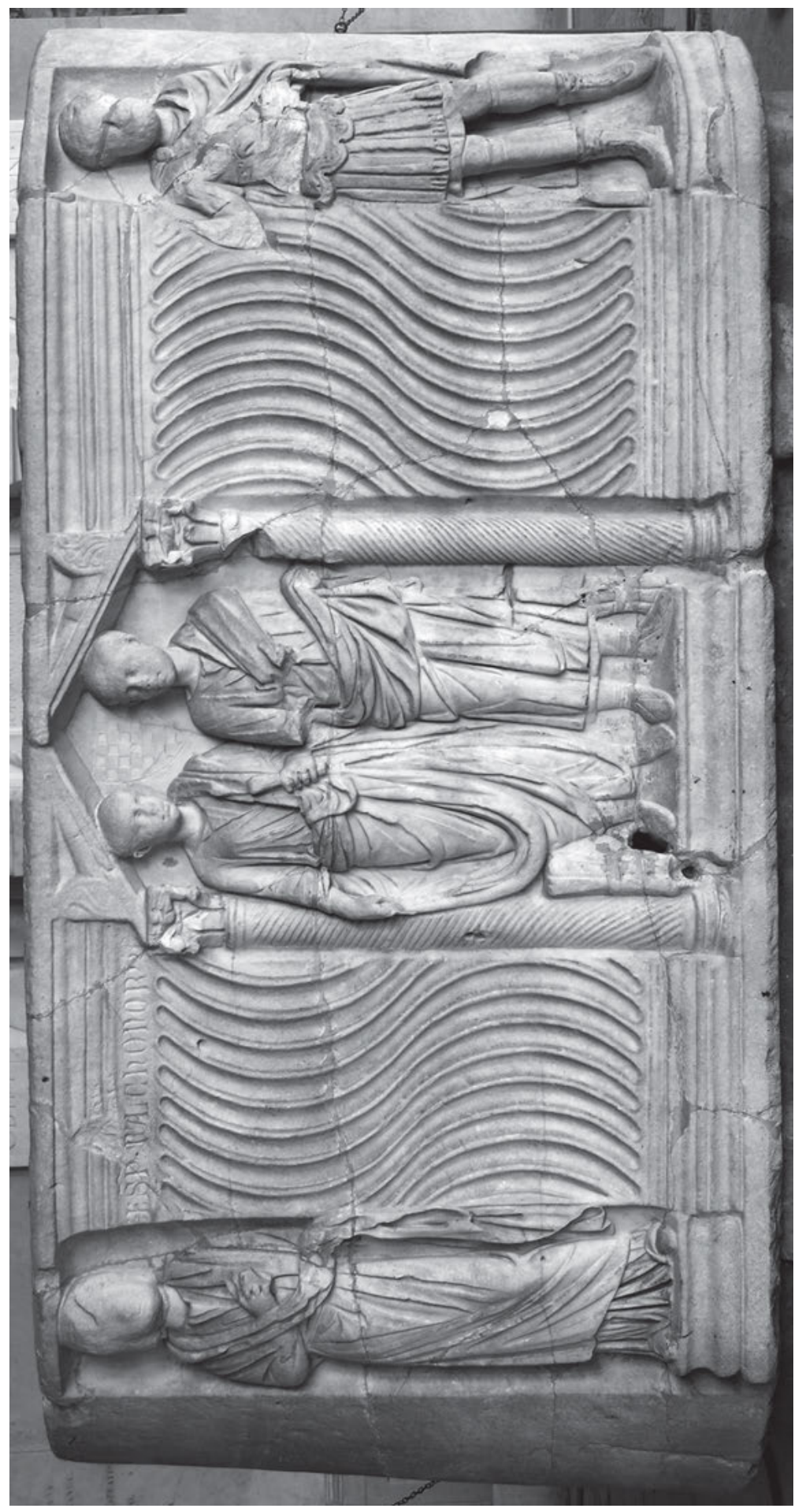

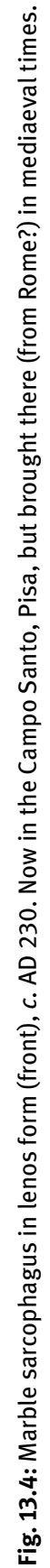

Bereitgestellt von | De Gruyter / TCS 


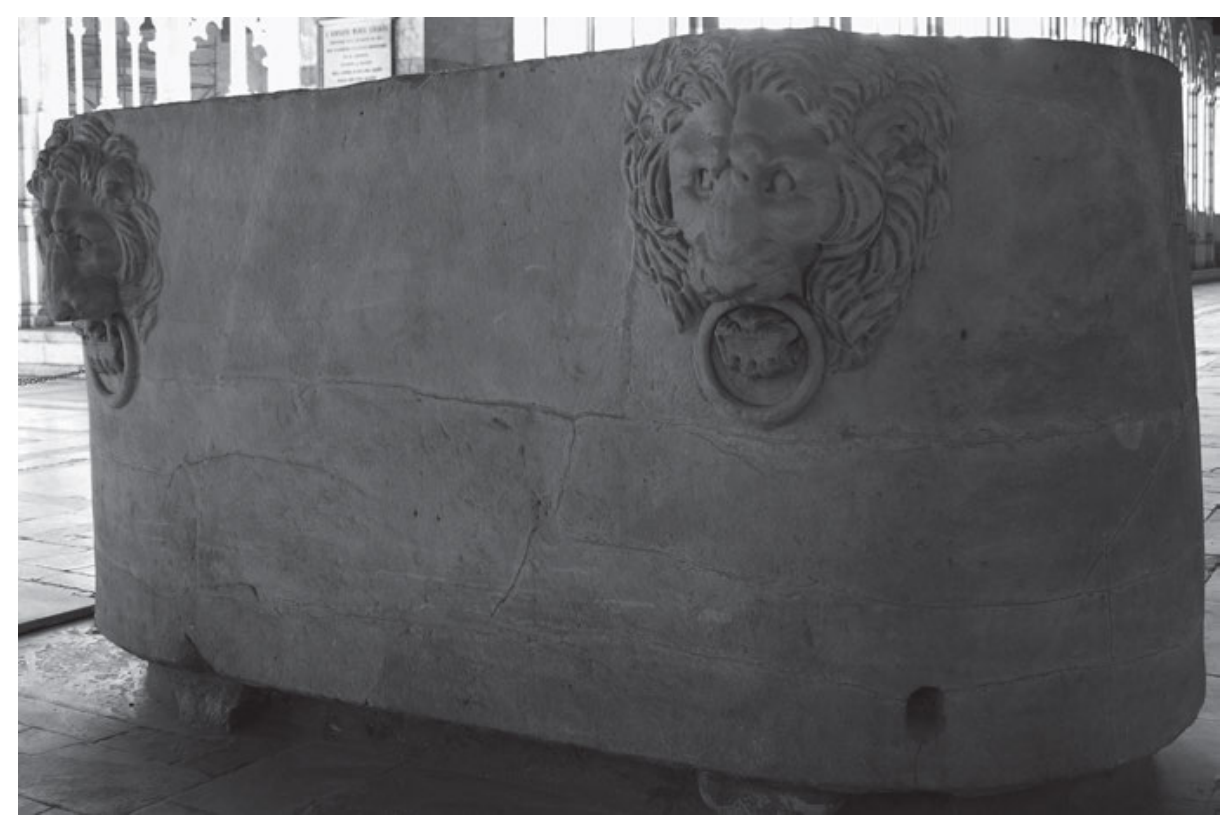

Fig. 13.5: Back view of the same sarcophagus.

Now, in both these cases we have an interesting play between the strigillated surface - moving, repetitive, without particular or differentiating features - and the attempt through columns, capitals and cornice to freeze a particular image of the deceased. Yet through their own strigillated ornamentation the columns comment on the strigillated panels and vice versa. There are many other examples in both pagan and Christian sarcophagi of this form of genuflection to the bigger decorative patterning of the base by the use of strigillated decoration on columns. ${ }^{40}$ These objects bring into sharp focus a play of parallel ornamental choices within different replicative elements of the decorative surface of single sarcophagi. But given the large numbers of such objects in antiquity (and even surviving into modernity) - with strigillation on columns even in caskets without strigillated panels and on panels in caskets without columns - the phenomenon may be thought also to offer sideways glances, playful allusions, comments on and to the general class of such objects. Mise en abyme within a single example in fact raises issues of self-reflection across the entire corpus. $^{41}$

40 E.g. Pesce 1957, no. 20; Bovini and Brandenburg 1967, nos. 83, 569, 658, 688, 921, 927; Matz 1975, nos. 290[?] (the central section cut out so we have only the aedicule), 306; Arias et al. 1977, nos. B 1 int. and C11 est.; Kranz 1984, no. 189; Sichtermann 1992, nos. 12, 13, 16; Reinsberg 2006, nos. 23 and 53.

41 It is rare to be able to nuance such general considerations against known archaeological context. 
A variation of the choice to place strigillation beside strigillated columns is the decision instead to use fluted columns. ${ }^{42}$ Here there is significant similarity of ornamental choices - regular grooves incised into the flat marble surface - but with the option taken in the columns to go straight rather than curved. Given the culture of strigillated columns on sarcophagi, the decision to use vertically fluted ones - especially in conjunction with panels of strigillation - is a distinctive case of conscious structural differentiation. One may say the same again for columns with no decoration..$^{43}$ An interesting example, also in Pisa, from the late second century, has a strigillated front with a strigillated column at either end (Fig. 13.6). In the centre and raised on a pedestal, above the lower border of the strigillated banding to either side, is an aedicule with fluted columns and tritons above the roofing, in which stands a couple in dextrarum iunctio (one takes it the pair intended to be buried in the coffin) ${ }^{44}$ with Concordia between them and a small Hymenaeus by their feet. ${ }^{45}$ The figures are very worn. The use of the various forms of decoration - aedicule with fluted columns, strigillated panels and strigillated columns - constructs a complex hierarchy of framing. The larger strigillated columns at the ends frame the entire facade, the ' $\mathrm{S}$ '-shapes of the strigillated panels radiate towards the central group, and the aedicule with its differentiated architectural decoration raises the figures depicted above and away from as well as within the larger decorative surface.

But a fine mid-third-century 'aedicule with an open door' strigillated sarcophagus with four strigillated columns, now in the American Protestant Church (St Paul's) in Rome, was found alongside three high-quality figured examples - showing Dionysiac themes, the Muses and a hunting scene - all from different moments in the third century, in the tomb of the Sempronii in Rome. In this case, the specific mise en abyme does not seem to have played out across the range of items used in the tomb. See Borg 2013, 126-130; Meinecke 2014, no. B11, 89-90, 237-240.

42 E.g. Matz 1975, nos. 282, 283, 285, 286, 303, 312, 313 (also - these are central sections cut out so as only to preserve the aedicule and not certainly from strigillated sarcophagi - 288, 289, 291, 310); Arias et al. 1977, C 7 est., C 9 int., D 4 int.; Kranz 1984, 167, 189, 400; Sichtermann 1992, 18; Stroszeck 1998, no. 205; Reinsberg 2006, nos. 35, 53, 56, 67, 109, 112.

43 E.g. Bovini and Brandenburg 1967, nos. 69, 87, 221, 397, 536, 568, 652 (if we trust the drawing), 659, 678, 778, 870; Matz 1975, nos. 44, 296, 308 and 309 (if we trust the drawings of the last two); Arias et al. 1977, nos. A 6 int., A 8 est., C 10 int.; Sichtermann 1992, nos. 11[?] (if correctly drawn), 14, 17; Reinsberg 2006, nos. 51, 139, 150.

44 On this motif on sarcophagi (including in strigillated examples), see Reekmans 1958; Huskinson 2012, 84-91; Studer-Karlen 2012, 107-115.

45 See Arias et al. 1977, no. A19 int.; Reinsberg 2006, no. 53. Cf. Bovini and Brandenburg 1967, no. 83 and Arias et al. 1977, D 3 int. for a similar configuration of columns and strigillation; for fluted and plain columns, see Arias et al. 1977, C 8 int. and C 18 int. (an interesting Good Shepherd). 


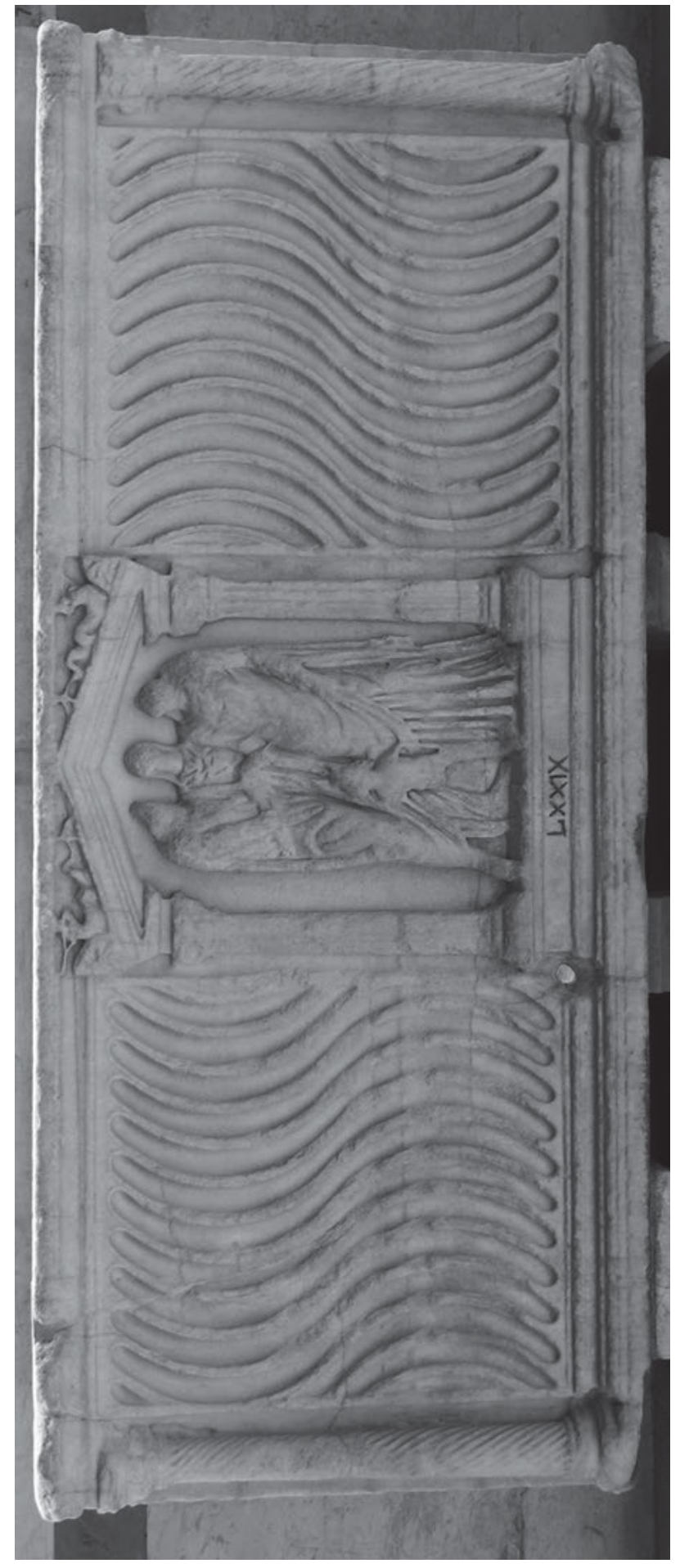

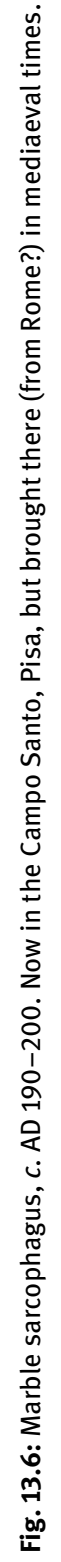

Bereitgestellt von | De Gruyter / TCS 


\section{Figural mise en abyme: The example of the double Narcissus}

In an example from the Vatican of the first half of the third century $\mathrm{AD}$, the central aedicule - with no decoration on its columns - has a couple in dextrarum iunctio with no base but with a small winged Hymenaeus holding a torch between them, who looks out at the viewer, unlike all the other figures on the casket (Fig. 13.7). ${ }^{46}$ Both figures have unfinished heads and are fully draped, the man carrying a scroll. In the pediment of the aedicule above them, there is a wreath and on its roof are hippocamps with long tails and theatrical masks. To either side panels of strigillation, framed top and bottom but not to left or right, flow in towards the centre. At the ends, to the far left and right, are nude images of Narcissus at the corners, both of them on statue bases, echoing each other in form and mirrored in a stance borrowed from a statue type of Narcissus (with little cupids on the inside alongside them). ${ }^{47}$ There are griffins on the two small sides, left and right. Both Narcissi on this casket are disrobed, their clothing draped over the trees that stand between them and the strigillated panels, marking the difference between a natural setting at the ends and an architectural, domestic space imagined for the couple in the centre. The postures of the two cupids are mirrored, both holding elevated torches, and standing over disembodied heads to which they are pointing, that appear to signify the reflected face of Narcissus in the pool, but also play against the theatrical masks of the pediment. Both Narcissi appear to use the same floral ornament in their hair - which itself reverberates against the wreaths in the pediment.

In this case there is a brilliant play of self-reflection, with the strigillated panels taking the place of flowing water and arguably each Narcissus reflecting the other through the eddies of strigillation, as it were, as well as being reflected in the head that lies at his feet. As in the case of the duplicated Gorgons' heads of the Pallavicini-Rospigliosi sarcophagus, which Narcissus is 'real' and which his reflection is impossible to say. What this casket offers is a superb visual version of the supreme literary and mythological mise en abyme of antique visuality, with both Narcissi figured as 'statues'. The circularity of these figures' mythical absorption plays with some poignancy and also perhaps a critical edge against the couple in the centre, apparently absorbed in each other. ${ }^{48}$ Each figured panel, including the couple, has a naked putto with a lighted torch; the couple standing in the centre are clothed, the two figures at the ends are not only naked, but have taken off their clothes which

46 See Reinsberg 2006, no. 150; Huskinson 2012, 82-83, 86; Huskinson 2015, 23-25. For Narcissus sarcophagi in general, see esp. Sichtermann 1986; Rafn 1992, esp. nos. 16, 17, 37, 38, 39; Koch and Sichtermann 1982, 167.

47 See e. g. Zanker 1966, esp. 159-166; Sichtermann and Koch 1975, 47.

48 So Huskinson 2012, 86. 


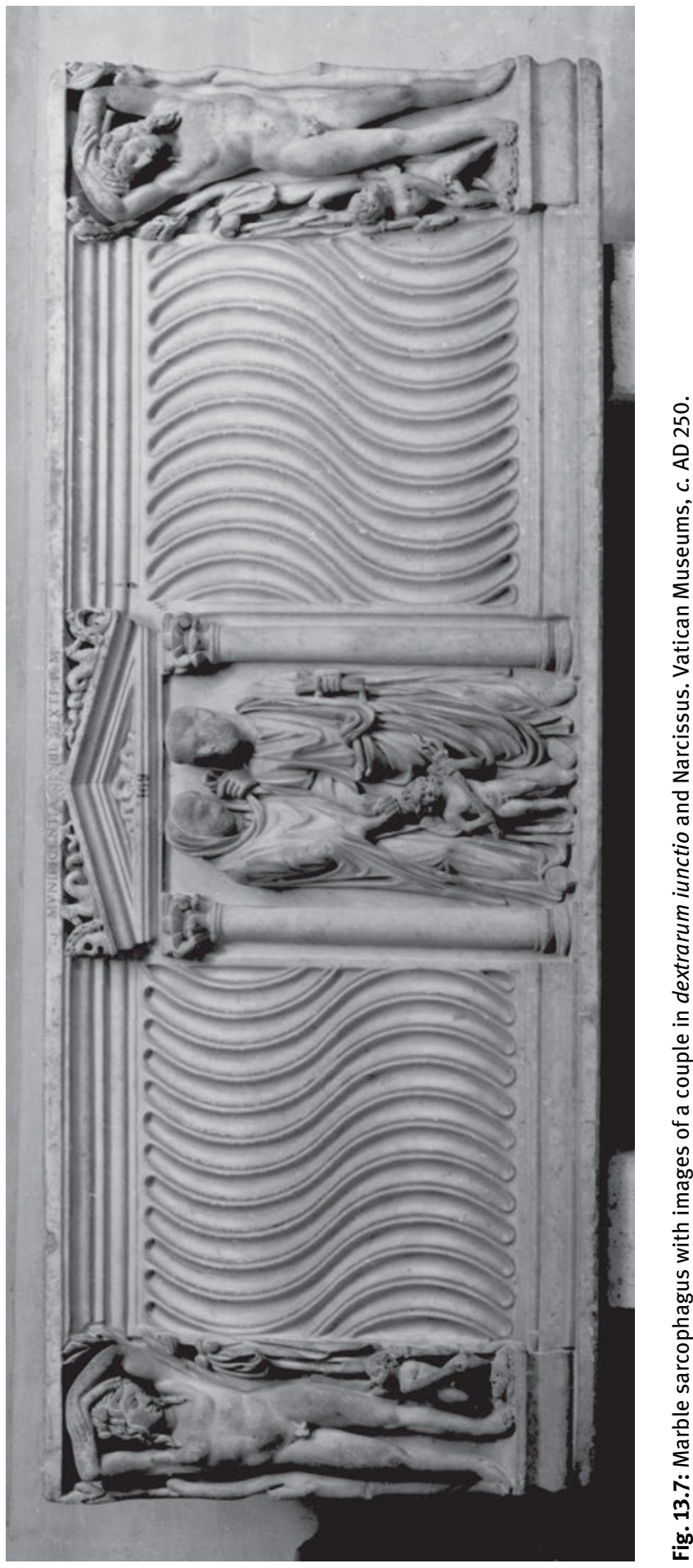

Bereitgestellt von | De Gruyter / TCS 
remain draped nearby. The pair in the aedicule have unfinished heads, the replicative pair that represent a single mythological figure have finished ideal heads. The couple in dextrarum iunctio are framed beneath the pediment and without a base; the Narcissi are elevated on pedestals but without an enclosing entablature above them. Here the couple appear as if in real life (without statue bases) while the Narcissi and their pedestals signal the artifice of sculpture. Yet the Narcissi stand as metaphors for the couple's immersion in love that this eulogistic imagery is surely meant to evoke, and they stand in nature as if entirely natural symbols for this love.

The same formal model of mirrored Narcissi and watery strigillation constitutes the structure of a five-panel sarcophagus with the three Graces in the centre, whose surviving front is now embedded in the stone decoration of Schloss Sanssouci in Potsdam, and which probably dates from the late second century (Fig. 13.8). ${ }^{49}$ In this case all the figures stand on bases, the whole group of Graces has a curtain for backing and water pots beside them. Again the disrobed Narcissi with their clothing draped over the trees to the sides are placed in a natural setting, while the curtain suggests a contained domesticity for the Graces. The Narcissi have their arms raised above their heads, following the statue type on which they are modelled, while the Graces have their arms lowered. Cupids stand to the sides of the Narcissi looking up at them, on the very outside edges of the sarcophagus. Clearly nudity, beauty and self-immersion in the strigil-like waters of love are heavily at stake and in play between the male and female figures, with water a suggestive aspect of all the figured scenes, since Narcissus is beside a pool while Graces have attendant jugs; in the context of watery imagery, strigillation certainly has the potential to suggest this theme - particularly in the way the curve of the lower outline of the strigillation falls past the cut-off line of each panel into the space created by the curve of the end of the Narcissisi's pedestals. The enmeshing of decorative strigillated panel with figural statue through the flow of strigillation into the indentation made by the statue base at each end of this piece is an excellent example of how this kind of art subverts any lingering reflex to insist on the absolute separation of 'figure' and 'ornament'. The mise en abyme of reflective Narcissi in the Sanssouci example is similar to the Vatican sarcophagus, but with the significant difference that there are no reflected heads at the feet of either Narcissus in the Potsdam example. This means that each statue image at the corner of the sarcophagus must be the reflection of the other across the surface of its relief sculpture through the prism of the strigillation and the beauty implied by the Graces..$^{50}$

49 See Sichtermann 1992, no. 159; Zanker and Ewald 2012, 233; Huskinson 2015, 9-11, 168.

50 Clearly very different issues are at play in those five-panel strigillated sarcophagi where Narcissus appears only at one end of the casket and not at both, for example, MNR no. 124741 (see M. Sapelli in Giuliano 1984, no. XII, 13, 379-380) or the piece in Volterra published by Sichtermann 1986, no. 5. 

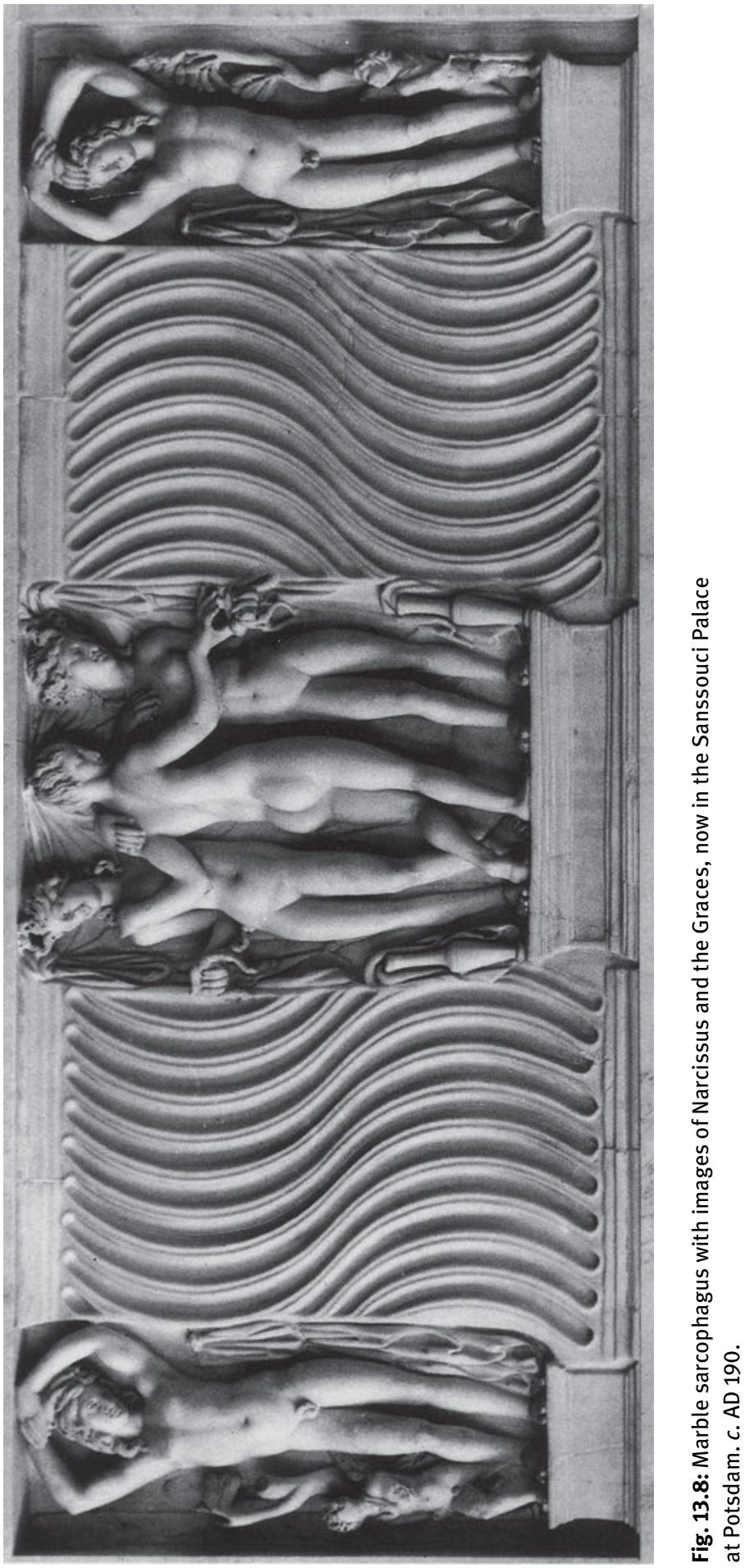

Bereitgestellt von | De Gruyter / TCS 
I have limited my account of the mise en abyme of figural types to strigillated sarcophagi and to the supreme mythological exemplar of the problem. ${ }^{51}$ But it is worth remarking briefly that the issue is much broader than this, with many instances of figural mise en abyme across the corpus of Roman sarcophagi. For example, briefly, one might mention the great Meleager sarcophagus in the Capitoline Museums where the boar-killing scene in the main front plays against a boar killing conducted by nude putti on the lid, with a putto conducting the death thrust in precise emulation of the hero, while the dogs beside each protagonist are in parallel (Fig. 13.9). ${ }^{52}$

\section{Strigillation: Aedicules and deities}

The particular pattern of a five-panel casket with strigillated sections and a central fluted aedicule is particularly popular in Dionysiac sarcophagi. ${ }^{53}$ The ends of such objects usually show a dancing maenad and satyr - in ecstatic worship of the god. In the centre Dionysus stands in revealed majesty - isolated from the rest of the casket in his aedicule, with the strigillated panels radiating out from him as if a flow of rays or perhaps of wine. The god may stand in isolation with attributes such as a panther or a thyrsus, ${ }^{54}$ or he may have the company of one or more satyrs. ${ }^{55}$ In the fine Proconnesian piece found in Rome about 1740 and now in the Fitzwilliam Museum in Cambridge, ${ }^{56}$ the maenad dances on her own playing cymbals to the far right, while the satyr on the left end, with a panther skin hanging to his right, carries a child. He has a panther between his feet, as well as the heads of a ram and a goat on the ground beside him (Fig. 13.10). In the centre Dionysus, beneath an aedicule with fluted columns, garlanded and crowning himself with ivy with his left hand, leans on a satyr to his left, who holds a panther skin like the one worn by the dancing satyr in the panel at the left end. Dionysus pours an offering from a kantharos in his right hand onto a ram's head on a pillar-like altar to his right. Behind him, above the altar, stands Pan with a human body but goat's head and legs, and to the right at the bottom is a cista with an emerging snake. Like the satyr on the end, Dionysus has a panther between his legs and in a reverse position from the one at the left end. The god's robe falls almost coquettishly behind him and over his right leg, in emulation

51 Generally, on mythological groupings on strigillated sarcophagi, see Kirchler 1990.

52 Koch 1975, no. 12.

53 For more on strigillated Dionysiac sarcophagi and potential relations with early Christian sarcophagi, see Elsner forthcoming b.

54 E.g. Matz 1975, 312 (panther and thyrsus), 313 (panther, Silenus mask and female herm).

55 E.g. Matz 1975, 282, 283, 285, 286, 288, 290, 291, 296, 303, 305, 306, 308, 309.

56 Matz 1975, 282; Budde and Nicholls 1964, no. 163, 103-104. 


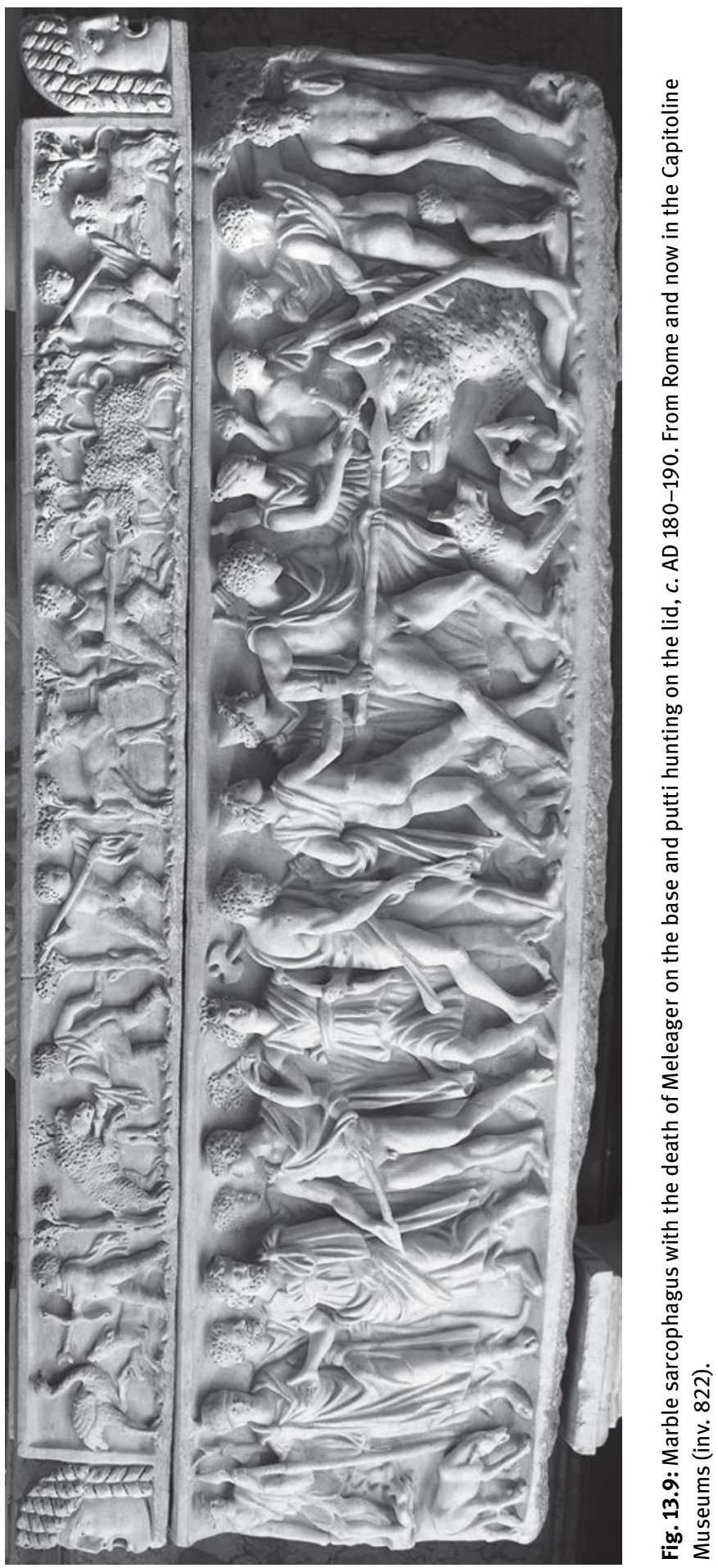

Bereitgestellt von | De Gruyter / TCS 


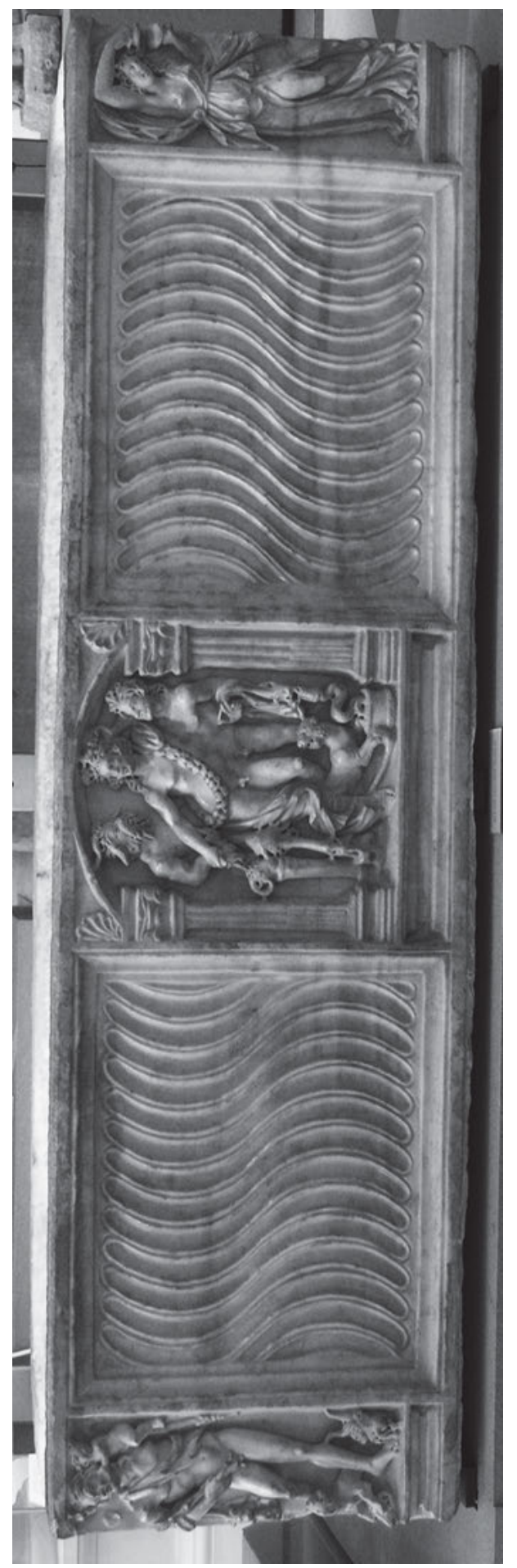

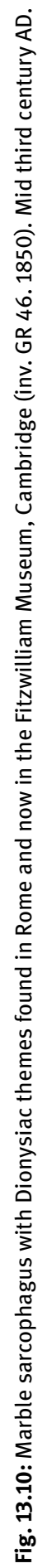


of the flowing robes of the maenad, out of which her left leg and naked right breast protrude.

This central group is packed with sacred referents (the god himself, the altar and libation, the cista and snake), the materials of ritual and of initiation as well as the divine being. Yet there are many iconographic correspondences among the figures: the panther skins of the two satyrs; the two panther figures between the legs of the left satyr and the god; the play between the living panthers and the pelts of dead ones; the rams' heads in the left side and in the centre; the decapitated goat's head in relation to Pan's goat's head (which is again a commentary on dead and living, very relevant to a funerary casket); the play of robes and nudity in the god and the maenad; and there are intimations of the senses across the whole casket - the clash of cymbals played by the maenad; the taste and sound of the wine poured by Dionysus; the sense of scent evoked by the altar; the urgency of movement throughout.

In the case of this sarcophagus, the figure scenes are all set off on statue bases with mouldings at the top and bottom, which themselves play on the mouldings of the bases of the fluted pilasters and the Corinthian capitals of the aedicule where the god stands. ${ }^{57}$ In other examples, there is no distancing through bases for any of the figures, ${ }^{58}$ or only the central group is depicted without a base (as in the Narcissus sarcophagus with a couple in dextrarum iunctio in the Vatican: Fig. 13.7).$^{59}$ Here, the decorative framing and the use of both aedicule and strigillation to set off the central sacred figure finds a parallel in (or at least resonance with) five-panel Christian sarcophagi, and may indeed have influenced their form. For instance, one might cite the casket found in Apt and now in Avignon which has apostles with scrinia at the left and right ends (perhaps Peter and Paul) facing into the centre, and Christ in a central aedicule with undecorated columns, with scrinium on the ground to the left (Fig. 13.11). ${ }^{60}$ Jesus carries a cross and faces a kneeling female figure to the right while making a gesture of blessing with his right hand. He seems to be stepping onto a footstool (or perhaps something offered by the small figure before him, whose left foot deliciously transgresses the frame of the aedicule and the border beneath, as if making a link to the viewer outside of the casket with the sacred image on its surface). ${ }^{61}$ As in the Cambridge Dionysiac example, a group including a deity, his acolytes and a range of sacred imagery (in this case, the large cross and the blessing gesture, in the Fitzwilliam example the libation, the altar and the cista) mark out the divine figure in the middle.

57 Cf. Matz 1975, nos. 284, 296, 309.

58 Cf. Matz 1975, nos. 283, 285, 308.

59 Cf. Matz 1975, nos. 286, 306, 312, 313.

60 See Christern-Briesenick 2003, no. 160. Other examples include aedicules made of trees: Bovini and Brandenburg 1967, nos. 682, 683, 829, 912.1, 990; and aedicules made of cloth: Bovini and Brandenburg 1967, nos. 73, 74, 396, 664, 739, 837.1.

61 Generally, on the motif of the woman before Christ, see Studer-Karlen 2012, 191-198. 


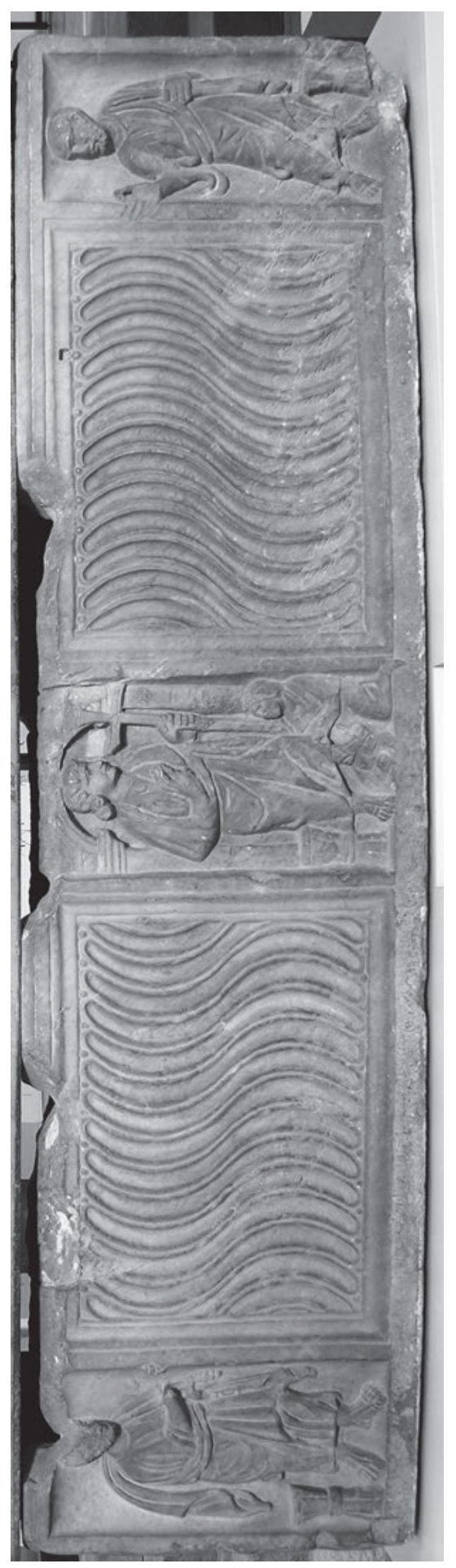

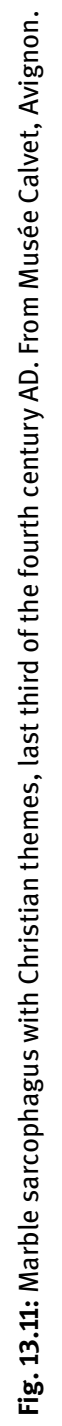


In all these cases the formal structure of columns, differently decorated, and panels of strigillation, can be used in a number of ways to set off subjects within a given sarcophagus and in relation to other sarcophagi. The framing possibilities and the option to set out the central scene as one of divine epiphany, with the end scenes indicating worship or mediation, offer a range of intriguing possibilities arising from the ornamental system itself in conjunction with the viewers' needs or demands for particular kinds of subject matter (in the case of both Christ and Dionysus, arguably for some kind of sacred emphasis). My point here, however, is not to get diverted into the rise of Christianity or into pagan religiosity, but simply to emphasise that all this is the result of the decorative logic of playing various replicative possibilities across a very particular and distinctive pictorial surface for ornamentation - namely a casket oblong in form and charged (for its viewers) by the fact that it contains the special remains of a human body. The very games of these sarcophagi, ultimately, play out thinking about the figurative and the ornamental, and above all the relationship between them.

\section{Strigillation: Images of vases and sarcophagi}

In addition to columns, there are other classes of object depicted on sarcophagi whose ornament calls attention to - and responds to - the strigillation of so many of them. One group, mainly of lion-head caskets, has entirely strigillated fronts of symmetrically arranged strigils making a small oval space in the centre - almost a mandorla in the later Christian sense - in which a small image is placed, its size being in some contradiction to its centrality in the visual field. ${ }^{62} \mathrm{~A}$ number of these caskets show vases in this space, ${ }^{63}$ and of these some examples are themselves strigillated. ${ }^{64}$ A fine lenos at San Martino ai Monti in Rome, from $c$. AD $250-260,{ }^{65}$ has lions attacking wild boar at either end, with what are apparently trainers for the arena standing behind them and gesticulating, with billowing cloaks (Fig. 13.12a). The main face comprises bands of strigillation that meet in the centre where a fluted pilaster holds up a kantharos with elegant strigillation at the neck (Fig. 13.12b). In this case none of the iconography

62 On mandorla motifs, see Baratta 2007 and Huskinson 2015, 191-193. A number of such themes represent Christian subjects, raising the issue of whether this formal structure does not in fact lie behind the Christian mandorla in later mediaeval art. See e.g. Stroszeck 1998, nos. 37, 116 (the Good Shepherd), 148, 212 (figures with scrolls), 271 (orant); Wegner 1966, no. 162 (Good Shepherd).

63 E.g. Stroszeck 1998, nos. 21, 69, 102, 189, 208, 211, 233, 277, 305, 340, 347, 367, 372, 373, 409 (a barrel); Baratta 2007, 207, made a catalogue with 22 barrels (discussion at 210-215), 21 craters and 12 amphorae (all large numbers comparatively within the full corpus).

64 E.g. Stroszeck 1998, nos. 234 and 332; Wegner 1966, no. 48.

65 Stroszeck 1998, no. 332. 
seems to speak in a clear way to the rest - the lion scenes, the strigillation and the kantharos appear not only to be independent elements (all situated in the appropriate place on the surface of the casket), yet to have no specific or thematic link with each other, as is often the case with such replicative imagery. But it is the very arbitrariness of the (lack of) thematic connections that appears to be signalled by the choice to make a formal link between the strigillation of the front and that of the vase. The same may be said of the example, from roughly the same date, now in the Pierpont Morgan library in New York, except that this has no lion handlers (so that its scenes of lion and boar could be imagined in the wild as well as in the circus) and no column whereon the kantharos sits. ${ }^{66}$

Again the resonance of these vases extends beyond the specific sarcophagi, on which they appear, to the larger range of strigillated vases that are found on other casket types such as the seasons sarcophagi, for instance.$^{67}$ If in fact the strigillated vase did have wider seasonal intimations in Roman visual culture, then this would potentially knit the imagery of the whole casket together - incorporating the death show of wild animals in the arena, the flow of strigillation and the seasonal suggestions of the vase in a sense of the movement of time set against the poignancy and potency that all these images relate the death of an individual commemorated inside the monument.

A particularly self-referential use of strigillation on a sarcophagus that is itself not in fact decorated with strigillated panels may be found on the great Adelfia sarcophagus now in Syracuse (Fig. 13.13). ${ }^{68}$ Here at the far left of the bottom of the two bands with Biblical themes that decorate the main base, Nebuchadnezzar stands beside his idol (Daniel 3: 1-18) - a bust portrait on a strigillated column with a Corinthian capital (Fig. 13.14). At the far right of the upper zone of decoration, Christ raises from the dead the son of the widow of Nain (Luke 7: 11-15) from a strigillated sarcophagus decorated exactly like the fronts of the lion sarcophagi, just discussed, with what may be intended to represent a tiny barrel - in fact the most popular of all such surviving motifs for this kind of sarcophagus - in the mandorla (Fig. 13.15). ${ }^{69}$ It may be the child's wrappings were themselves intended to reflect the wrappings of corpses buried inside sarcophagi. ${ }^{70}$ The use of strigillation in relation to a long prior visual discourse of sarcophagi is powerful in this object - it directly ties the visual theme to death through the medium

66 Stroszeck 1998, no. 234.

67 Kranz 1984, 3, 31 (fluted), 119, 123, 125, 384, 472, 517, 542; Reinsberg 2006, no. 44.

68 See Greco 1998; Dresken-Weiland 1998, no. 20; briefly Baratta 2007, 208.

69 Other strigillated sarcophagi represented on sarcophagi, all in versions of the same Christological theme: Bovini and Brandenburg 1967, nos. 40, 527, 776 (a poor survival but the sarcophagus may have been strigillated); Christern-Briesenick 2003, nos. 70, 366, 439. For the iconography of the resurrections of Jairus' daughter and the youth of Nain on sarcophagi, see Nauerth 1980, 5-33 and Koch 2000, 164-165 and 166-167.

70 For this point in relation to Lazarus imagery, see Meinecke 2014, 129. 


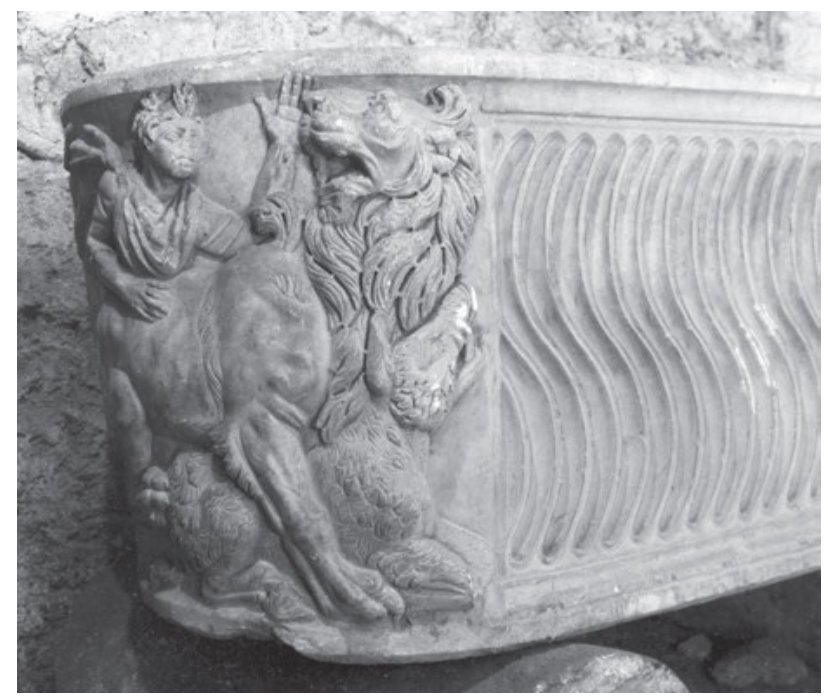

Fig. 13.12a: Marble lenos sarcophagus with lions and lion tamers at the sides, and strigillation in the main face, c. AD 250-260. From Rome and now at San Martino ai Monti. Detail of the left side.

of decorative strigillation used on this form of monument and hence through the iconography chosen to the theme of Christian resurrection. This act is itself set against the strigillation of a column carrying an idol that defines the paganism from which Christ's incarnation has saved the world. ${ }^{71}$ The parallelism of the birth of Jesus on the lid, lying in similar posture to the child of Nain, his head swaddled similarly and in a similar casket, but done as if in wickerwork rather than strigillation, itself emphasises the incarnational motif, again through the use of artefacts and their ornamental decoration, in ways very similar to the play of boar-killings on the Meleager sarcophagus from the Capitoline Museums (Fig. 13.9). ${ }^{72}$ On this remarkable casket, pivoting the lower left-hand side of the front against the upper right, strigillation as a self-reflexive mise en abyme - that brings to mind a whole world of Roman image-making and through it a whole world of Roman life and culture - defines both idolatry and Christian salvation and functions as a marker for the paganism from which Christianity had saved the world, as well as for resurrection itself.

What the Adelfia sarcophagus demonstrates is that the replicative motifs and decorative embellishments of Roman art, at least on sarcophagi, can themselves be exploited for powerful ideological and thematic ends in an object sophisticated enough to make a visual argument. More frequent than the depiction of sarcophagi

71 For more on the image of Nebuchadnezzar, see Elsner 2011, 380-382 and Elsner 2014b, 344-347. 72 See Elsner 2012, 184. 


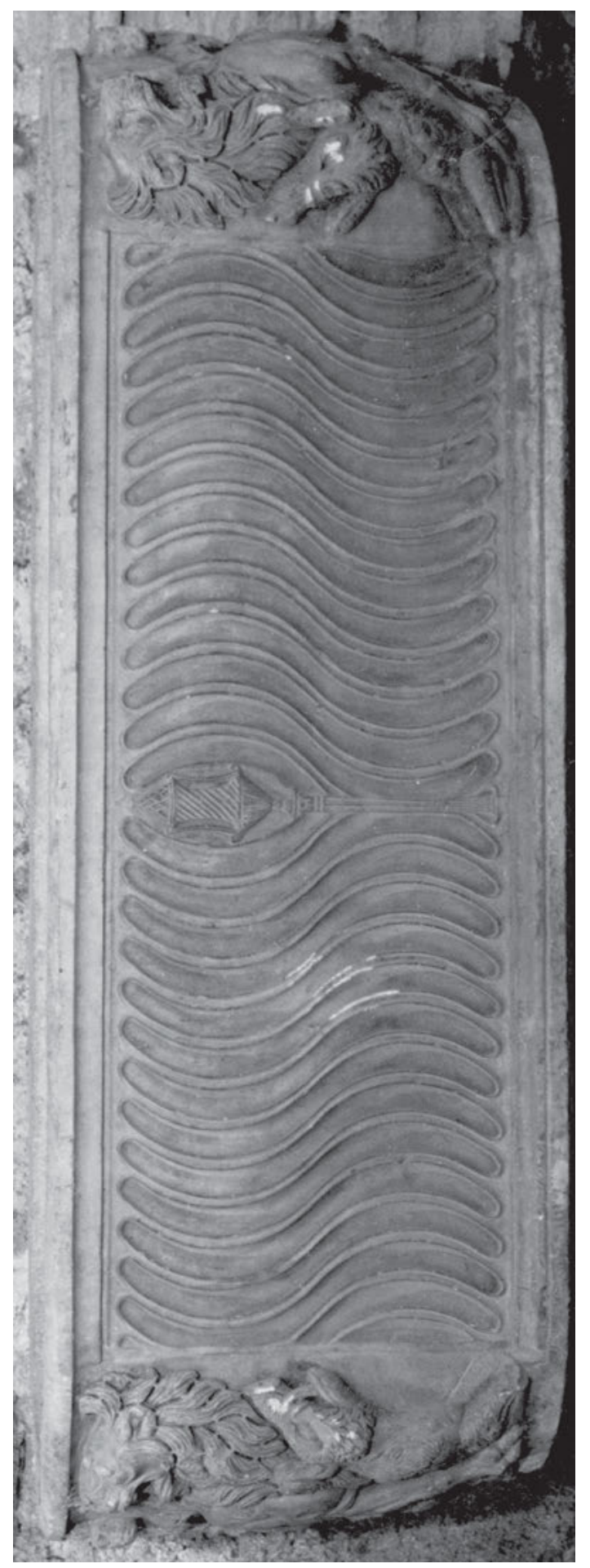

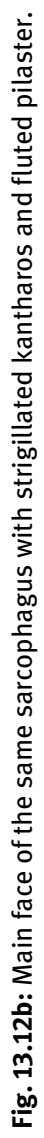

Bereitgestellt von | De Gruyter / TCS 


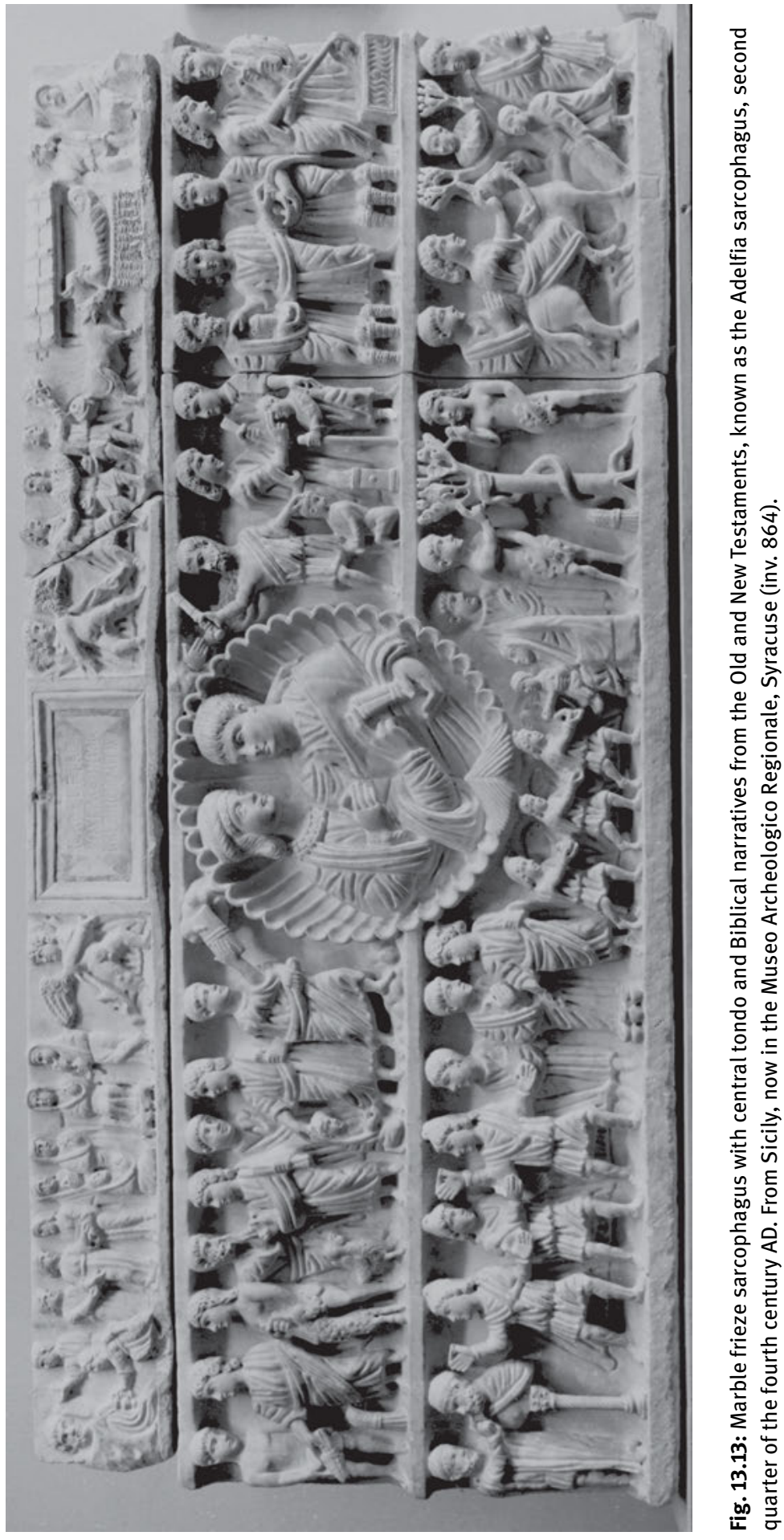




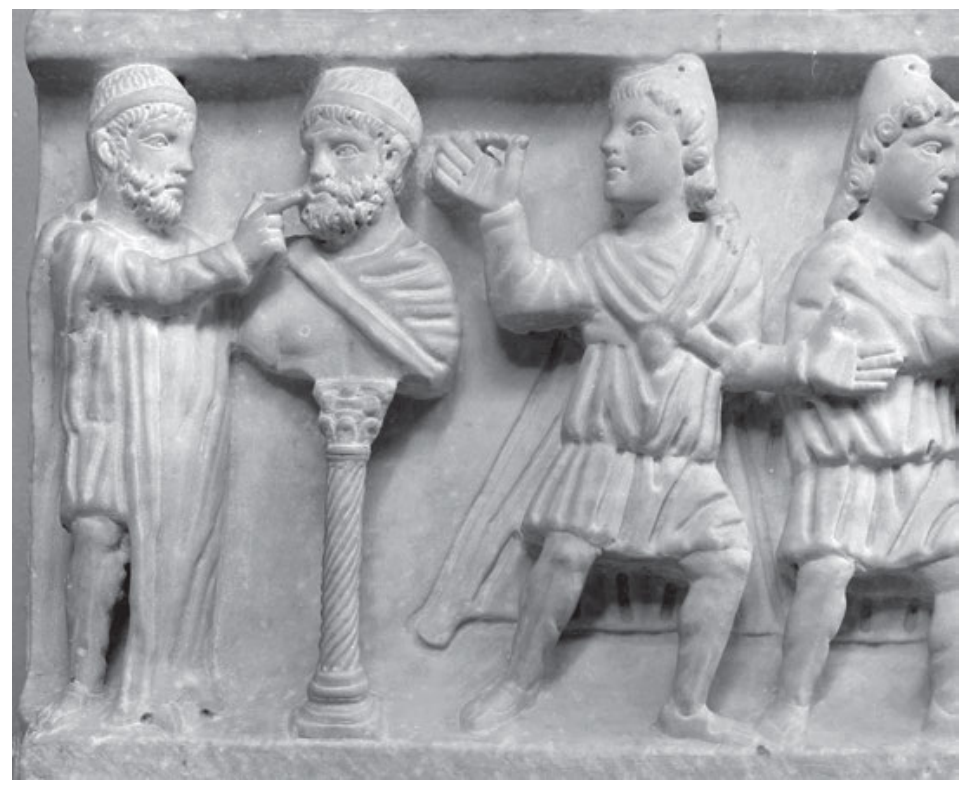

Fig. 13.14: Detail of the Adelfia sarcophagus, from the left side of the lower register. The scene shows Nebuchadnezzar ordering the Hebrews to worship his idol.

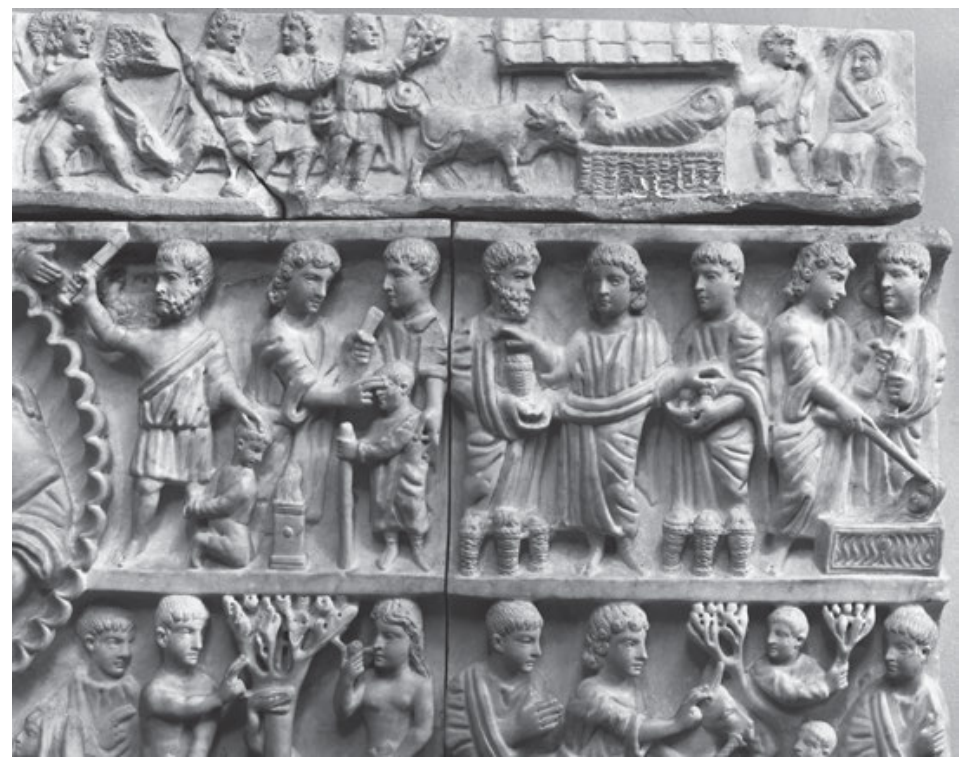

Fig. 13.15: Detail of the Adelfia sarcophagus, showing the right side of the lid and upper tier of the main face. The lid shows the Magi and the Nativity, the upper tier shows the sacrifice of Isaac, Christ healing the blind man, the miracle of the loaves, Jesus raising the son of the widow of Nain from a strigillated sarcophagus. 
on sarcophagi is the use of sarcophagus-shaped objects, whether for narrative themes such as Noah's Ark, ${ }^{73}$ or for Dionysiac themes such as the trampling of grapes by putti in lenos- or square-shaped basins. ${ }^{74}$ In the latter case these are frequently decorated with sarcophagus-like ornamentation - notably lions' heads (arranged very like those on lion-headed sarcophagi) and sometimes with tendrils and other kinds of Dionysiac decoration..$^{75} \mathrm{~A}$ wonderful example is the child's sarcophagus once in Castle Howard and now in the British Museum, dating to $c$. AD 260-280 (Figs. 13.16a-d) ${ }^{76}$ A lenos carved on all four sides, this has lions' heads with rings in them on both long sides. Mixed human and animal figures - Silenus, centaurs - appear on the curves between the two sets of lions' heads (Figs. 13.16c and 13.16d), while between the lions' heads on the two long sides are two groups with human-like figures: Dionysus leaning on an acolyte with a maenad playing the tambourine and a panther on one side (Fig. 13.16a), and three putti trampling grapes on the other (Fig. 13.16b). All the male figures are nude. The grapes are trampled in a lenos-shaped wine-press, that looks like a sarcophagus and has lions' heads carved on it in the same position as those on both sides of this sarcophagus and indeed of so many lion-headed caskets. Now the kinds of meanings one might read into this - for instance, the transformation of matter within a sarcophagus-shaped casket to create something divine and ecstatic, as grapes can be turned into wine - are numerous. They are not predetermined or forced, but naturally arise as potential interpretations for viewers on the basis of all the replicative uses of motifs and their juxtaposition in mise en abyme.

\section{Conclusions}

I have been attempting to argue that the replicative logic that operated throughout Roman art in the deployment of the relatively limited number of types and motifs across rather formulaic and themselves replicated surface shapes - in this case, the restricted longitudinal and 'landscape'-format surface of Roman sarcophagi - offers an alternative model for understanding decoration in relation to meaning from that

73 See Elsner 2012, 184-185 and Studer-Karlen 2012, 174-178. Examples include Bovini and Brandenburg 1967, nos. 23, 35, 41, 46, 121, 133, 143, 145, 155, 364, 834, 836, 959, 987.

74 See Bielefeld 1997: undecorated basins: nos. 16, 20[?], 29, 48, 50[?], 56, 57, 65, 72, 75, 79, 80, 86, 91, 113, 116, 118, 123, 134, 142 (left end), 151, 155, 159, 179, 183, 193[?], 194, 202[?], 213, 217, 218; minimally decorated basins: nos. 37, 146, 162, 194, 221, 222; decorated with scrolls, which may perhaps suggest Dionysiac subject matter: nos. 4, 77, 129, 139, 142, 158; decorated with lions' heads, like the lions' sarcophagi: nos. 39, 40, 45, 47, 74, 96, 104[?], 108, 112, 125, 131, 140, 150, 154, 178, 185, 192, 196, 208, 211, 214, 227, 228; decorated with lions' heads and scrolls: nos. 46, 49, 53, 141 and 174, or decorated with lions' heads and a putto in between: no. 117. For some discussion, see Elsner 2012, 182-184.

75 See the examples above at n. 74 and Matz 1968, nos. 37, 39, 40.

76 See Oehler 2005; Kranz 1999, no. 21; Bielefeld 1997, no. 45 and Stroszeck 1998, no. 11. 


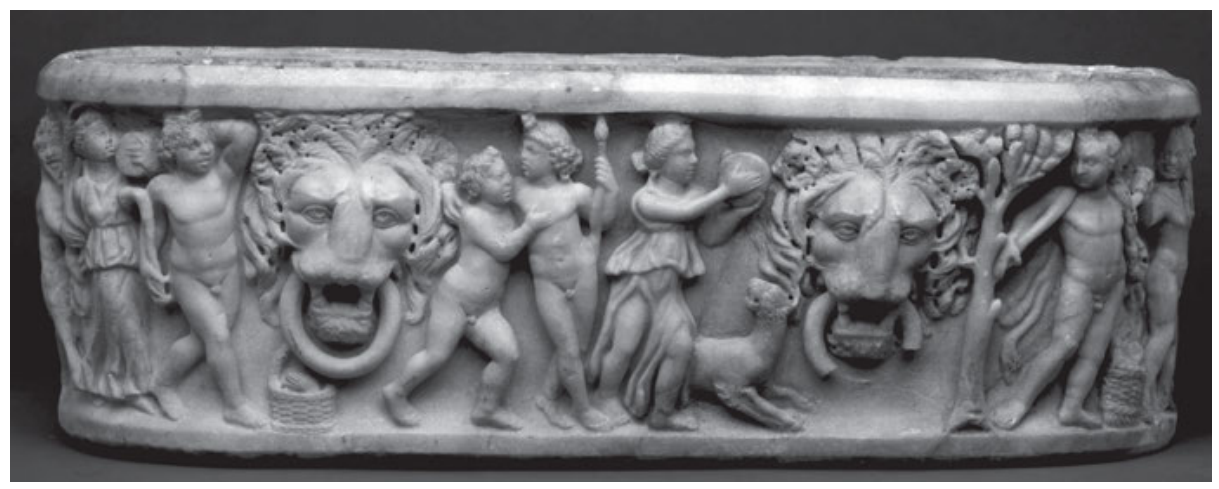

Fig. 13.16a: Child's sarcophagus in lenos form with Dionysiac subject matter and lions' heads, c. AD 260-280. Probably from Rome and now in the British Museum (inv. 1996,0301.1). Front of the sarcophagus with Dionysus and his entourage between lions' heads.

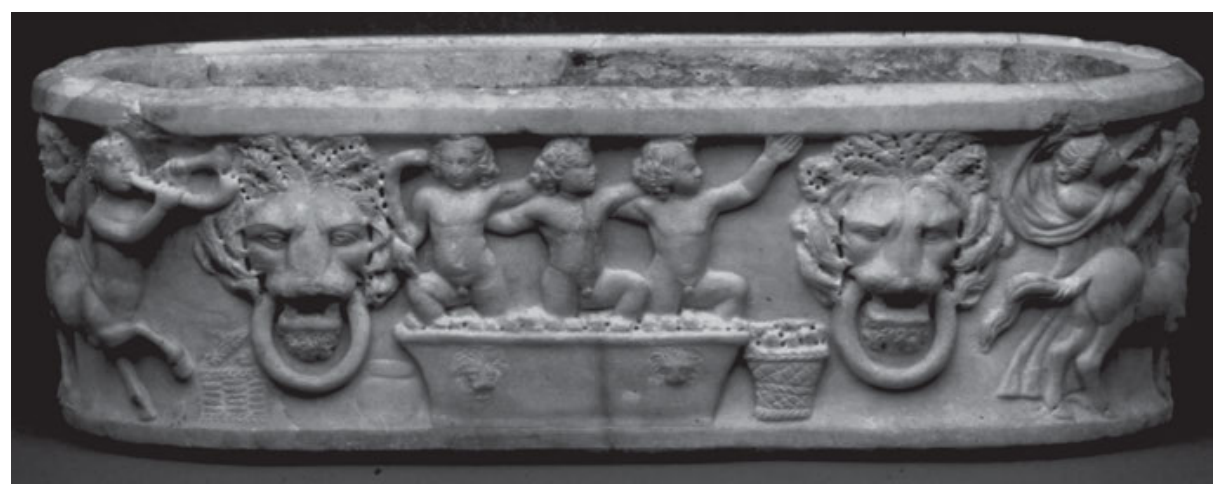

Fig. 13.16b: Back of the same sarcophagus with lions' heads and between them a scene of putti pressing grapes in a lenos-shaped tub with lions' heads.

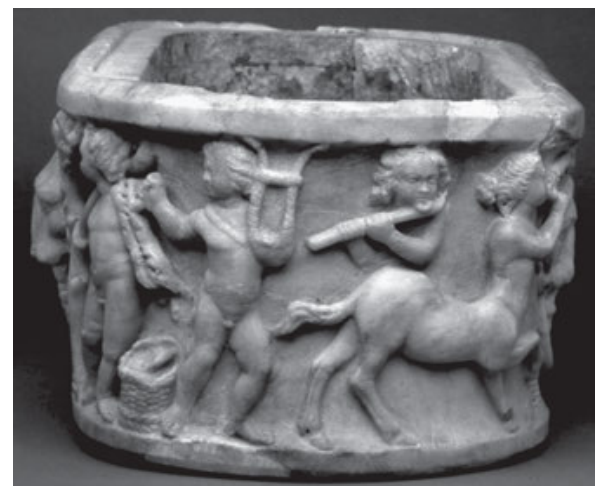

Fig. 13.16c: Left end of the same sarcophagus with centaur and procession.

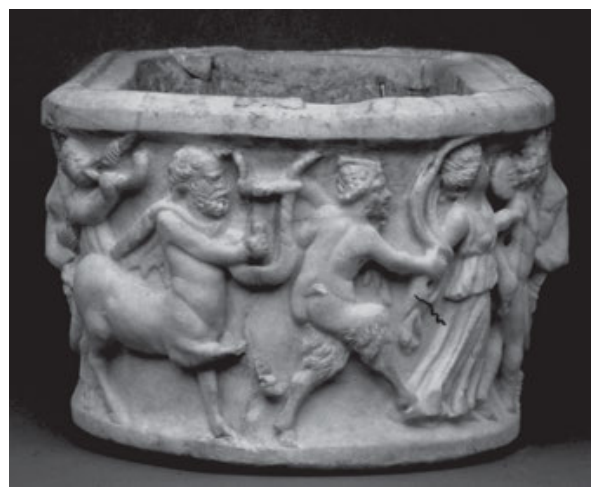

Fig. 13.16d: Right end of the same sarcophagus - with centaur, satyr and dancing maenad. 
normal in the history of art, at any rate since the work of Erwin Panofsky. ${ }^{77}$ Panofsky's famous iconological model for the study of art history divided the field into three levels - forms and styles, subject matter and iconography, and ultimately meaning and symbolic values. ${ }^{78}$ I have been arguing that the deployment of formal decorative motifs (effectively Panofsky's first level of iconology) created the subject matter and iconographies from which - at the level of the viewer's reception, in relation to the larger range of the ways in which such types and motifs were normally seen meaning was generated at the point of the spectator's contact. In the case of sarcophagi, the principal control on the range and diversity of meaning was the fact of death and the consolatory purpose of these monuments, with their very specific function of actually containing the deceased. What this means is that, at the most fundamental starting point for the analysis of Roman art, we cannot artificially separate Panofsky's three levels, as he did, but that - at any rate in the case of Roman art - decorative formalism, subject matter and iconography, and the realm of meaning are entirely united, each playing upon and generated by the others. We may not have the means always to identify the full range of literary and cultural referents with which a given item of iconography might have been replete in antiquity, as we may more easily do in later periods, when the evidential base is richer and the array of relevant texts more numerous; but what we can do with Roman art is to identify the ways in which forms and types, motifs and repeated models generate the visual artefact.

It is worth adding here that, on the formal level, as I have been arguing, there is strikingly little difference between 'pagan' sarcophagi and the corpus of Christian examples - their funerary functions, decorative tropes, replicative typologies and willingness to play the game of mise en abyme were strikingly close, interconnected and parallel, often using the same artists and workshops, we may assume. However, at the point of the viewer's contact and construction of meaning, there were significant differences. In part, these related to a different understanding of the dead body inside the coffin (as one that was capable of salvation and indeed resurrection at the ending of days, in the Christian model). In part, these differences related to the fact that while Christian narrative 'mythology' may seem to have been deployed in very similar ways to pagan mythological narratives - not only in the frieze and columnar figured sarcophagi but also in the five-panel strigillated versions, and in both cases often combined with portrait medallions of the deceased - by contrast, in the Christian context such narrative 'mythology' was grounded in written-down and canonical Scripture rather than frequently changing and often partly oral myth, and tied to increasingly authoritative (not to say potentially authoritarian) models of exegesis,

77 The key works are Panofsky 2012 (first published in 1932); Panofsky 1939, 3-17; and Panofsky 1955, 26-54.

78 For a sustained discussion of Panofskian art historical method in relation to classical art, see Lorenz 2016, esp. 17-100. 
interpretation and reading promulgated with extraordinary urgency by the fathers of the church in the fourth century. ${ }^{79}$

The regularity (if not vast frequency) of what I have identified as mise en abyme in sarcophagi was one way of calling attention to, and offering pause to think about, the nature of a relatively limited system of replicative options, types and motifs. The repetition of these types and motifs could in fact give rise to a vast quantity of quite individualised, and sometimes highly original, works of art. Such mise en abyme within the corpus put in focus the frequent, indeed ubiquitous, way in which no one motif or figure or iconographic formulation of several figures was in fact unique - but rather all played with, commented on, or reflected back on the range of others in the corpus, notably the particular examples (possibly numerous) which the artist or the viewer had seen and remembered. There was clearly a broad range of collective cultural meanings that such objects and their representations had even within the limited scope of mise en abyme - that is their formally replicated reflections on other objects in the corpus or visual system. But meanings were always also individualised because viewers' experiences of the range of other objects, like the given sarcophagus one might be looking at, were so different. This was true even in a relatively discrete cultural context such as the city of Rome in, say, the Severan period, let alone across the entire Roman Empire over the three centuries (early second to early fifth centuries AD) when the vast quantity of our surviving sarcophagi were produced.

What these objects show is a remarkable diversity of differentiation on the level of the object within strikingly restricted formal and typological constraints (the size, shape and decorative range of sarcophagi). But they also imply, in parallel, a wide range of potential interpretative responses at the subjective level of the viewer's interrogation of the objects within the limited formal constraints and the fundamental thematic focus on death, mourning and consolation. It is this dialogue of object-formalism and subjective-response that is at the heart of understanding the 'ornamental' - as indeed the 'figurative' - in the Roman world.

79 See Huskinson 2015, 207-237, for developments of Christian strigillated sarcophagi in the fourth century AD. 


\section{Bibliography}

Amedick, R. (1991) Vita Privata aus Sarkophagen (= Die antike Sarkpophagreliefs 1.4). Berlin.

Andreae, B. (1984) 'Bossierte Porträts auf römischen Sarkophagen: Ein ungelöstes Problem’, Marburger Winkelmann Programm 1983: 109-128.

Anguissola, A. (2005) 'Roman copies of Myron's Discobolus', Journal of Roman Archaeology 18: 317-335.

Anguissola, A. (2012) Difficillima imitatio: immagine e lessico delle copie tra Grecia e Roma. Rome.

Arias, P., Cristiani, E. and Gabba, E. (1977) Camposanto monumentale di Pisa. Le antichità I: sarcofagi romani, iscrizioni romane e medioevali. Pisa.

Baratta, G. (2007) 'La mandorla centrale dei sarcophagi strigilati: un campo iconografico ed i suoi simboli', in Römische Bilderwelten, eds. F. Hölscher and T. Hölscher. Heidelberg: 191-215.

Beyer, V. and Spies, C. (2011) 'Einleitung. Ornamente und Ornamentale: Modi des Bildes', in Ornament: Motiv, Modus, Bild, eds. V. Beyer and C. Spies. Paderborn: 13-23.

Bielefeld, D. (1997) Die stadtrömischen Eroten-Sarkophage. Weinlese- und Ernteszenen, (= Die antike Sarkpophagreliefs 5.2.2). Berlin.

Birk, S. (2013) Depicting the Dead: Self-Representation and Commemoration on Roman Sarcophagi with Portraits. Aarhus.

Borg, B. (2013) Crisis and Ambition: Tombs and Burial Customs in Third-century CE Rome. Oxford.

Bovini, G. and Brandenburg, H. (1967) Repertorium der christlich-antiken Sarkophage I: Rom und Ostia. Wiesbaden.

Budde, L. and Nicholls, R. (1964) A Catalogue of the Greek and Roman Sculpture in the Fitzwilliam Museum. Cambridge.

Camille, M. (1992) Image on the Edge: The Margins of Medieval Art. London.

Chiarlo, C. (1974) 'Sul significato dei sarcofagi a "lenos" decorati con leoni', Annali della scuola normale superiore di Pisa (Classe di lettere e filosofia) 3.4.4: 1307-1345.

Christern-Briesenick, B. (2003) Repertorium der christlich-antiken Sarkophage III: Frankreich, Algerien, Tunisien. Mainz.

Dällenbach, L. (1989) The Mirror in the Text. Cambridge.

Derrida, J. (1987) The Truth in Painting, trans. G. Bennington and I. McLeod. Chicago.

Dresken-Weiland, J. (1998) Repertorium der christlich-antiken Sarkophage II: Italien mit einem Nachtrag Rom und Ostia, Dalmatia, Museen der Welt. Mainz.

Engemann, J. (1973) Untersuchungen zur Sepulkralsymbolik der späteren römischen Kaiserzeit. Münster.

Elsner, J. (2007) Roman Eyes: Visuality and Subjectivity in Roman Art. Princeton.

Elsner, J. (2011) 'Apology and polemic in early Christian sarcophagi: Reflections on Jesus' trial', in J. Elsner and J. Huskinson (eds.): 359-386.

Elsner, J. (2012) 'Decorative imperatives between concealment and display: The form of sarcophagi', RES: Anthropology and Aesthetics 61/2: 178-195.

Elsner, J. (2014a) 'Introduction', in J. Elsner and M. Meyer (eds.): 1-34.

Elsner, J. (2014b) 'Rational, passionate and appetitive: The psychology of rhetoric and the transformation of visual culture from non-Christian to Christian sarcophagi in the Roman world', in J. Elsner and M. Meyer (eds.): 316-349.

Elsner, J. (forthcoming a) 'The embodied object: Recensions of the dead on Roman sarcophagi', in The Embodied Object in Classical Antiquity (= Art History 41.3), eds. M. Gaifman, V. J. Platt and M. J. Squire. London.

Elsner, J. (forthcoming b) 'Some observations on Dionysiac sarcophagi', in Visual Histories: Visual Remains and Histories of the Classical World: Papers in Honour of R. R. R. Smith, eds. C. Draycott, R. Raja, K. Welch and W. Wootton. Leiden. 
Elsner, J. and Huskinson, J. (eds.) (2011) Life, Death and Representation: Some New Work on Roman Sarcophagi. Berlin.

Elsner, J. and Meyer, M. (eds.) (2014) Art and Rhetoric in Roman Culture. Cambridge.

Elsner, J. and Squire, M. J. (2016) 'Sight and memory: The visual art of Roman mnemonics', in M. J. Squire (ed.): 180-204.

Ewald, B. (1999a) 'Sarkophage und Marmorkleinfunde', Mitteilungen des Deutschen Archäologischen Instituts Rom 106: 335-339.

Ewald, B. (1999b) Der Philosoph als Leitbild. Mainz.

Focillon, H. (1942) The Life of Forms in Art. New Haven.

Furtwängler, A. (1893) Meisterwerke der Griechischen Plastik. Kunstgeschichtliche Untersuchungen. Leipzig.

Galinier, M. (2013) ‘À vendre: les sarcophages romains dans les ateliers, suggestions méthologiques’, in M. Galinier and F. Baratte (eds.): 81-116.

Galinier, M. and Baratte, F. (eds.) (2013) Iconographie funéraire romaine et societé. Perpignan.

Gazda, E. (2002) The Ancient Art of Emulation: Studies in Artistic Originality and Tradition from the Present to Classical Antiquity. Ann Arbor, MI.

Gide, A. (1943) Journal I (1889-1912). Rio de Janeiro.

Giuliano, A. (1984) Museo Nazionale Romano: le sculture 1.7, vol. II. Rome.

Greco, G. (1998) Et lux fuit: le catacombe e il sarcofago di Adelfia. Palermo.

Grethlein, J. (2016) 'Sight and reflexivity: Theorizing vision in Greek vase-painting', in M. J. Squire (ed.): 85-106.

Gütschow, M (1931) 'Sarkophag-Studien I', Mitteilungen des Deutschen Archäologischen Instituts Rom 46: 90-118.

Hallett, C. (1995) 'Kopienkritik and the works of Polykleitos', in Polykleitos, The Doryphoros and Tradition, ed. W. G. Moon. Madison, WI: 121-160.

Hardie, P. (2002) Ovid's Poetics of Illusion. Cambridge.

Harris, W. (2015) 'Prolegomena to a study of the economics of Roman art', American Journal of Archaeology 119: 395-417.

Herdejürgen, H. (1996) Stadrömische und Italische Girlandensarkophage I (= Die antike Sarkpophagreliefs 6.2.1). Berlin.

Hölscher, T. (2004) The Language of Images in Roman Art. Cambridge.

Hölscher, T. (2009) 'Architectural sculpture: messages? Programs? Towards rehabilitating the notion of "decoration", in Structure, Image, Ornament: Architectural Sculpture in the Greek World, eds. P. Schultz and R. von den Hoff. Oxford: 54-67.

Huskinson, J. (1998) ““Unfinished portrait heads” on later Roman sarcophagi: Some new perspectives', Papers of the British School at Rome 46: 129-158.

Huskinson, J. (2011) 'Habent sua fata: Writing life histories of Roman sarcophagi’, in J. Elsner and J. Huskinson (eds.): 55-84.

Huskinson, J. (2012) 'Reading identity on Roman strigillated sarcophagi', RES: Anthropology and Aesthetics 61/62: 80-97.

Huskinson, J. (2015) Roman Strigilated Sarcopahgi: Art and Social History. Oxford.

Ișik, F. (2007a) Girlanden-Sarkophage aus Aphrodisias. Mainz.

Ișik, F. (2007b) ‘Lokalisierung der Werkstätten der Girlanden Sarkophage aus kleinasiatischen Hauptgruppen', in Akten des Symposiums des Sarkophag-Corpus 2001: Marburg, 2.-7. Juli 2001, ed. G. Koch. Mainz: 279-297.

Junker, K., Stähli, A. and Kunze, C. (eds.) (2008) Original und Kopie: Formen und Konzepte der Nachahmungen in der antiken Kunst. Wiesbaden.

Kant, I. (1987) Critique of Judgment, trans. W. Pluhar. Indianapolis. 
Kirchler, M. (1990) 'Mythologische Gruppen auf romischen Reifelsarkophagen', in Echo: Festschrift J. B. Trentini, eds. B. Otto and F. Ehrl. Innsbruch: 179-185.

Koch, G. (1975) Die Mythologischen Sarkophage VI Meleager (= Die antike Sarkpophagreliefs 12.6). Berlin.

Koch, G. (2000) Christliche Sarkophage. Munich.

Koch, G. and Sichtermann, H. (1982) Römische Sarkophage. Munich.

Kousser, R. (2008) Hellenistic and Roman Ideal Sculpture: The Allure of the Classical. Cambridge.

Kranz, P. (1984) Jahreszeiten-Sarkophage. Entwicklung und Ikonographie des Motivs der vier Jahreszeiten auf klassischen Sarkophagen und Sarkophagdeckeln (= Die antike Sarkpophagreliefs 5.4). Berlin.

Kranz, P. (1999) Die stadtrömischen Eroten-Sarkophage. Dionysischethemen (= Die antike Sarkpophagreliefs 5.1). Berlin.

Lippold, G. (1923) Kopien und Umbildungen griechischer Statuen. Munich.

Lorenz, K. (2011) 'Image in distress? The death of Meleager on Roman sarcophagi', in J. Elsner and J. Huskinson (eds.): 309-336.

Lorenz, K. (2016) Ancient Mythological Images and their Interpretation: an Introduction to Iconology, Semiotics and Image Studies in Classical Art History. Cambridge.

Mack, R. (2002) 'Facing down Medusa (an aetiology of the gaze)', Art History 24: 571-604.

Marvin, M. (1993) 'Copying in Roman sculpture: The replica series', in Roman Art in Context: An Anthology, ed. E. D’Ambra. Englewood Cliffs, NJ: 347-384.

Matz, F. (1968) Die Dionysischen Sarkophage, (= Die antike Sarkpophagreliefs 4.1). Berlin.

Matz, F. (1975) Die Dionysischen Sarkophage (= Die antike Sarkpophagreliefs 4.4). Berlin.

Meinecke, K. (2013) 'Funerary cult at sarcophagi: Rome and vicinity', in M. Galinier and F. Baratte (eds.): 31-50.

Meinecke, K. (2014) Sarcophagum Posui. Römische Steinsarkophage im Kontext. Wiesbaden.

Nauerth, C. (1980) Vom Tod zum Leben. Wiesbaden.

Newby, Z. (2014) 'Poems in stone: Reading mythological sarcophagi through Statius' Consolations', in J. Elsner and M. Meyer (eds.): 256-287.

Nock, A. D. (1946) 'Sarcophagi and symbolism', American Journal of Archaeology 50: 140-170.

Oehler, H. (2005) 'Kindersarkophag', in Die antiken Skuplturen in Castle Howard, eds. B. Borg, H. von Hesberg and A. Linfert. Wiesbaden: 145-147.

Panofsky, E. (1939) Studies in Iconology: Humanistic Themes in the Art of the Renaissance. Oxford.

Panofsky, E. (1955) 'Iconography and iconology: An introduction to the study of Renaissance art', in Meaning in the Visual Arts. New York: 26-54.

Panofsky, E. (2012) 'On the problem of describing and interpreting works of the visual arts (1932)', Critical Inquiry 38: 467-482.

Perry, E. (2005) The Aesthetics of Emulation in the Visual Arts of Ancient Rome. Cambridge.

Pesce, G. (1957) Sarcofagi romani di Sardegna. Rome.

Platt, V. (2012) 'Framing the dead on Roman sarcophagi', RES: Anthropology and Aesthetics 61/62: 212-227.

Platt, V. J. and Squire, M. J. (2017) 'Introduction: Framing the visual in Greek and Roman Antiquity', in V. J. Platt and M. J. Squire (eds.): 1-99.

Platt, V. J. and Squire, M. J. (eds.) (2017) The Frame in Classical Art: A Cultural History. Cambridge.

Rafn, B. (1992) 'Narkissos', Lexicon Iconographicum Mythologiae Classicae 6.1: 703-711.

Reekmans, L. (1958) 'La “dextrarum iunctio” dans l'iconographie romaine et paléochretienne', Bulletin de l'institut historique Belge de Rome 31: 23-96.

Reinsberg, C. (2006) Die Sarkophage mit Darstellungen aus dem Menschenleben 3 (Vita Romana) (= Die antike Sarkpophagreliefs 1.3). Berlin. 
Ridgway, B. (1984) Roman Copies of Greek Sculpture: The Problem of the Originals. Ann Arbor, MI. Russell, B. (2013) The Economics of the Roman Stone Trade. Oxford.

Settis, S. (ed.) (2015) Serial/Portable Classic. Milan.

Sichtermann, H. (1986) 'Narkissos auf römischen Sarkophagen', in Studien zur Mythologie und Vasenmalerei. Konrad Schauenburg zum 65. Geburtstag, eds. E. Böhr and W. Martini. Mainz: 239-242.

Sichtermann, H. (1992) Die Mythologischen Sarkophage. Apollon bis Grazien (= Die antike Sarkpophagreliefs 12.2). Berlin.

Sichtermann, H. and Koch, G. (1975) Griechische Mythen auf römischen Sarkophagen. Tübingen.

Squire, M. J. (2011) The lliad in a Nutshell: Visualizing Epic on the Tabulae lliacae. Oxford.

Squire, M. J. (2013) 'Ekphrasis at the forge and the forging of ekphrasis: The "Shield of Achilles" in Graeco-Roman word and image', Word \& Image 29(2): 157-191.

Squire, M. J. (ed.) (2016) Sight and the Ancient Senses. London.

Stroszeck, J. (1998) Die dekorativen römischen Sarkophage. Die Löwen-Sarkophage: Die Sarkophage mit Löwenköpfen, schreitenden Löwen und Löwenkampfgruppen (= Die antike Sarkpophagreliefs 6.1). Berlin.

Studer-Karlen, M. (2012) Verstorbenendarstellungen auf frühchristlichen Sarkophagen. Turnhout. Trimble, J. (2011) Women and Visual Replication in Roman Imperial Art and Culture. Cambridge. Turcan, R. (1999) Messages d'outre-tombe. Paris.

Wegner, M. (1966) Die Musensarkophage (= Die antike Sarkpophagreliefs 5.3). Berlin.

Wrede, H. (1981) 'Kliniensarkophage', Archäologischer Anzeiger: 86-131.

Zanker, P. (1966) '“Iste ego sum”: Der naive und der bewuste Narziß’, Bonner Jahrbücher 166: 152-170.

Zanker, P. and Ewald, B. (2012) Living with Myths: The Imagery of Roman Sarcophaagi. Oxford.

\section{Image credits}

Fig 13.1: After Herderjürgen 1996, Taf. 91.1 (kat. 127) (Photograph by Wrede).

Fig. 13.2: DAl 81.4533 (Photography by Schwanke).

Fig. 13.3: Photograph by Jaś Elsner.

Fig. 13.4: Photograph by Jaś Elsner.

Fig. 13.5: Photograph by Jaś Elsner.

Fig. 13.6: Photograph by Jaś Elsner.

Fig. 13.7: DAI 1971.1709 (Photography by Singer).

Fig. 13.8: After Zanker and Ewald 2012, 233, fig. 212.

Fig. 13.9: Photograph by Jaś Elsner.

Fig. 13.10: Photograph by Jaś Elsner.

Fig. 13.11: Photograph by Jaś Elsner.

Fig. 13.12a: DAI 1967.456 (Photography by Hutzel).

Fig. 13.12b: DAl 1967.451 (Photography by Hutzel).

Fig. 13.13: DAl 1971.859 (Photography by Singer).

Fig. 13.14: DAl 1971.0863 (Photography by Singer).

Fig. 13.15: DAl 1971.861 (Photography by Singer).

Fig. 13.16a: (C) Trustees of the British Museum.

Fig. 13.16b: ๑ Trustees of the British Museum.

Fig. 13.16c: ๑ Trustees of the British Museum.

Fig. 13.16d: (๑) Trustees of the British Museum. 
Bereitgestellt von | De Gruyter / TCS

Angemeldet

Heruntergeladen am | 22.03.18 09:47 